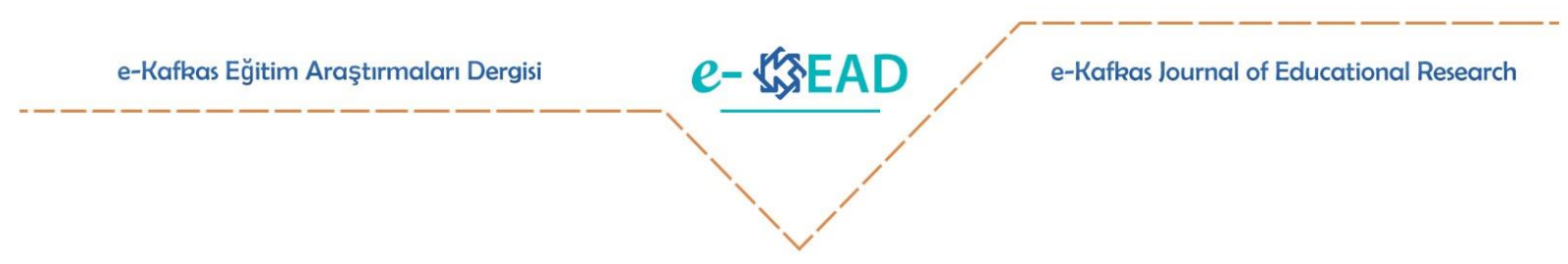

\title{
Anasınıfına Devam Eden Çocukların Matematiksel Akıl Yürütme Becerilerine Piyano Destekli Müzik Etkinliklerinin Etkisi*
}

\section{The Effect of Piano-Assisted Music Activities on the Mathematical Reasoning Skills of the Preschoolers*}

\section{Ceren DOĞAN (1) $\triangle$ Belir TECIMER (i) $\triangle$}

Atıf: Doğan, C.; Tecimer, B. (2019). Anasınıfına devam eden çocukların matematiksel akıl yürütme becerilerine piyano destekli müzik etkinliklerinin etkisi. e- Kafkas Ĕ̆itim Araştırmaları Dergisi, 6(3), 13-33.

Araştırma Makalesi Geliş Tarihi:09.09.2019 Kabul Tarihi:28.12.2019

Doi: 10.30900/kafkasegt.617233

\section{$\ddot{O} \mathbf{z}$}

$\mathrm{Bu}$ araştırmanın amacı anasınıfına devam eden 5-6 yaş grubundaki çocukların erken matematiksel akıl yürütme becerilerine piyano destekli müzik etkinliklerinin etkisini tespit etmektir. Araştırmada Ön-test son-test kontrol gruplu deneysel desen kullanılmıştır. Araştırmanın çalışma grubu deney grubunda 16, kontrol grubunda 16 olmak üzere toplam 32 çocuktan oluşmaktadır. Çalışma grubu Ankara ilinden tesadüfi olarak seçilmiş iki ana sınıfıdır. Her etkinlik planının uygulanması 30 dakika kadar sürmüş, uygulamadan önce pilot çalışma yürütülmüştür. Kontrol grubuna araştırmacı tarafından bir uygulama yapılmamış, anasınıfı öğretmeni tarafından Milli Eğitim Bakanlığı 2013 Okul Öncesi Eğitim Programı kapsamında günlük müzik etkinlikleri yapılmıştır. Veri toplama aracı olarak Ergül tarafından 2014'te geliştirilen “Erken Matematiksel Akıl Yürütme Becerileri Değerlendirme Aracı” kullanılmıştır. Ölçeğin ölçme-tümevarım, ölçme-tümdengelim, veri analizi ve olasılıktümevarım, veri analizi ve olasılık-tümdengelim olmak üzere dört alt boyutu bulunmaktadır. Verilerin analizinde Mann-Whitney U testi ile hipotezler test edilmiştir. Araştırma sonucunda, piyano destekli müzik etkinliklerinin erken matematiksel akıl yürütme becerilerinde etkili olduğu görülmüştür.

Anahtar Sözcükler: Erken matematiksel akıl yürütme, Erken matematiksel beceriler, Piyano eğitimi, Müzik eğitimi, okul öncesi eğitim

\begin{abstract}
The primary purpose of this research is to determine the effect of piano-assisted music activities on the early mathematical reasoning skills of preschoolers. The experimental design of the pre-test post-test with a control group was used. The experimental group has 16 children, the control group consisted of 16 children and the study group had 32 children. The study group was two randomly selected preschool classes from Ankara. An eight-week program of piano-assisted music activity plan was developed by the researcher. Each activity duration is 30 minutes. A pilot study was held before the experiment. The "Early Mathematical Reasoning Ability Assessment Tool", developed by Ergül in 2014, was used for data collection. The sub-dimensions of the tool were measurement-induction, measurement-deduction, data analysis and probability-induction and data analysis and probability-deduction. For the data analysis, hypotheses were tested by the Mann-Whitney U test. Within the light of the findings, it was seen that piano-assisted music activities are effective in preschoolers' early mathematical reasoning skills.
\end{abstract}

Keywords: Early mathematical reasoning, Early mathematical skills, Piano education, Music education, Preschool education

\footnotetext{
* Bu çalışma birinci yazarın Gazi Üniversitesi Eğitim Bilimleri Enstitüsü tarafından kabul edilen Anasınıfına Devam Eden 60-72 Aylık Çocukların Matematiksel Akıl Yürütme Becerilerine Piyano Destekli Müzik Etkinliklerinin Etkisi (2018) isimli doktora tez çalışmasının bir bölümü olup, 33. World Conference of International Society for Music Education (2018) isimli kongrede sözlü bildiri olarak sunulmuştur.
} 


\section{Giriş}

Evrensel dili ile çocukların farklı diller ve kültürlerle tanışmasını mümkün kılan müzik eğitiminin matematiksel mantık ile problem çözme alanlarında da başarıyı arttıracağı düşünülmektedir. Çalgı eğitimi ve özellikle piyano eğitiminin erken bilişsel becerilere etkisi ile ilgili çalışmaların dünyada örnekleri bulunsa da (Rauscher, Shaw, Levine, Wright, Dennis, \& Newcomb, 1997; Billharts, Bruhn, \& Olson, 2000) ülkemizde müzik eğitiminin bilişsel becerilere etkisi üzerine sınırı sayıda çalışmalar bulunmaktadır (Dikici, 2002; Kaya \& Ayan, 2016; Kuşçu, 2010). Çalg1 eğitiminin özellikle akıl yürütme ve matematiksel becerilere etkisi ile ilgili bir çalışmaya ise ulaşılamamıştır. $\mathrm{Bu}$ bağlamda, bu araştırma anasınıfına devam eden 5-6 yaş grubundaki çocukların erken matematiksel akıl yürütme becerilerine piyano destekli müzik etkinliklerinin etkisini tespit etmeyi amaçlamaktadır. $\mathrm{Bu}$ amaç doğrultusunda, araştırmanın çalışma grubunda yer alan çocukların oluşturduğu deney ve kontrol gruplarının;

1. "Erken matematiksel akıl yürütme becerileri ön-test/son-test puan ortalamaları üzerinde deney grubu lehine anlamlı bir fark var mıdır?"

2. "Erken matematiksel ak1l yürütme becerileri ölçme alt boyutunda ön-test/son-test puan ortalamaları üzerinde deney grubu lehine anlamlı bir fark var mıdır?"

3."Erken matematiksel akıl yürütme becerileri veri analizi-olasıllk alt boyutunda ön-test/sontest puan ortalamaları üzerinde deney grubu lehine anlamlı bir fark var mıdır?" sorularına yanıt aranmıştır.

\section{Erken Matematiksel Akıl Yürütme}

Mantık ve akı1 yürütme sözcükleri akı1, söz ve düşünce boyutlarıyla ilişkilidir. Mantığın bir alt boyutu olan akıl yürütmede özellikle vurgulanan noktalar, karar vermek ve doğru çıkarımlarda bulunarak mantığa nazaran daha somut sonuçlar elde etmektir. Günlük yaşantıda bir engelle karşılaşan ya da bir sorunu çözmek durumunda kalan insan, bilerek ya da bilmeyerek, bir dizi bilişsel sürecin düzenli biçimde çalışmasına gereksinim duyar. Çoğunlukla bellekte depolanmış olarak bulunan, benzer durumlarda kullandığı yollar ve yöntemlerden yararlanarak engeli aşmaya, sorunu çözmeye çalışır. Yine de geçmişte, farklı koşullarda geçerli olan yol ve yöntemler, güncel sorunun çözülmesinde geçerli ve yeterli olmayabilir. Bu durumda karşılaşılan durumu düşünmek, incelemek, geçmiş deneylerden yararlanarak, edinilmiş bilgilerin 1şığı altında belirli ilkeler ve kurallar içinde yeni kararlar almak gerekir. Bilişsel işlevlerin bir bütün olarak birlikte çalışıp oluşturduğu bu sürece akıl yürütme (muhakeme) adı verilmiştir. Akıl yürütme sonuca ulaştığında engeli aşmak ve sorunu çözmek için gerekli olan davranış, tutum ve eylem belirlenmiş olur (Köknel, 2003).

Akıl yürütme, bütün etmenleri dikkate alarak düşünüp akılcı bir sonuca ulaşma sürecidir, matematikte gerçeklere deney ve gözlemle değil, yalnızca akıl yürütme ile ulaşılır. $\mathrm{Bu}$ nedenle matematikteki tüm kuralların ve işlemlerin temelinde akıl yürütme vardır. (Aladağ, 2009). Başarılı problem çözülebilme, akıl yürütme sayesindedir. Kişinin akıl yürütme becerisi ne kadar yüksekse aslında o kadar başarılı olacaktır çünkü akıl yürütme becerisi olayları farklı bakış açıları ile değerlendirme ve yeni durumlara transfer etme imkanı sunar (Bal-İncebacak \& Ersoy, 2016). Para harcama, zamanı tahmin etme, seyahat planlama ya da yemek pişirme gibi günlük yaşamın bir parçası olan pek çok faaliyet matematiksel işlem gerektirir. Bu tür matematiksel işlemler daha çok tümdengelimsel akıl yürütmeyle ilişkilidir. Öte yandan benzeşim tümevarımlı bir akı1 yürütme şeklidir ve düşünen kişinin verilen bilgilerin ötesine gitmesini sağlar (Goswami, 2004).

Akıl yürütme türleri, gözlemlenen belli olgulardan genelleme yapmak ve genellemelerden belli sonuçlara ulaşmak olmak üzere iki tür hareket içerir. Belli olgulardan evrensel bir yargıya varmak yoluyla kullanılan akıl yürütme yöntemi tümevarım olarak adlandırılır. Genel bir gerçekten yola çıkıp bunun belli durumlara uygulanmasında kullanılan akıl yürütme yöntemi ise tümdengelimdir (Fathima \& Rao, 2008).

Akıl yürütme, zaman zaman doğru sonuçlara ulaşamayabilir. Sınıf ortamında sık sık kusurlu akıl yürütmelerle karşılaşılabilir. Kusurlu akıl yürütme, yanlış sonuçlara rağmen öğrencilerin nasıl düşündüğünün ipuçlarını verir. İlk bakışta doğru gibi gözüken kusurlu akıl yürütme, çoğu zaman bilinen yöntemlerin ve genellemelerin yanlış durumlara uyarlanması sonucu oluşur. Yine kusurlu akıl 
yürütmenin sorgulanması öğrencilere kendi kavrayışlarını ve kurdukları ilişkiler ağını tanımaları, açıklamaları, savunmaları ve nerede kusurlu düşündüklerini anlama firsatı tanır (Umay, 2003).

Çocuklar çok erken yaşta akıl yürütmeye başlamaktadır, ancak bu akıl yürütme erişkin kişilerin akıl yürütmesinden farklılık gösterir. Çocuk iki-dört yaşlarında düşüncelerinde bireyler ve nesneler hakkında genelleme yapmaya başlar. Özelden genele ve genelden özele akıl yürütme türlerinin ikisi de çocuğun düşünme şeklinde gözlemlenebilmektedir (Fathima \& Rao, 2008). Çocuklarda akıl yürütme, psikolojik bir süreç olarak çeşitli sembollerle sinırlanmamaktadır. Çocuk, oldukça ileri bir yaşa varıncaya kadar tümdengelim türünde düşünce genel önermeler ve genellemeler gerektirmesi sebebiyle söz konusu olmaz. Çocuk genelleme yapabilmeye başladığ 1 ilk zamanlar bile kişisel inançlarından sıyrılamadığı ve başkaları tarafından ortaya atılan herhangi bir varsayım üzerinde akıl yürütme gerçekleştiremediği için formel tümdengelime yabancı kalır (Piaget, 2011).

Bilişsel gelişim evreleri olan duyu-motor, işlem öncesi, somut işlemler ve soyut işlemler dönemlerinin her birinde çocuk farklı bilişsel yetenekler kazanmaktadır. Alt evrelerdeki bilişsel yetenekler sonraki düşünme becerileri için temel oluşturur ve daha yüksek evreyle bütünleşir (Gander \& Gardiner, 2010). Piaget'e göre, özellikle 2-7 yaş arasında çocukların akıl yürütme sırasında mantıksal düşünemedikleri görülmektedir. Bir önceki dönem olan duyu-hareket dönemine kıyasla daha ileri bir bilişsel düzeyde olmalarına rağmen, akıl yürütme durumlarının henüz mantıksal bir kararlılığa ve sistematiğe sahip olmadığını düşünülmektedir (Dehart, Sroufe, \& Cooper, 2004). Piaget'e göre dört-yedi yaş sinıflama, eşleştirme, sıralama, karşılaştırma becerileriyle mantıksal düşünmeye geçiş dönemidir. (Altıparmak \& Öziş, 2005).

Matematiksel akıl yürütme matematiksel tahminleri oluşturma, matematiksel tartışmaları geliştirme ve değerlendirme, matematiksel bilgileri çeşitli şekilde sunma becerilerini içermektedir. Matematiksel akıl yürütme, konuya göre cebirsel, orantısal, istatistiksel ve geometriksel; düşünme tarzına göre pratik ve soyut; bakış açısına göre ise analitik ve bütünsel olmak üzere üç türde sınıflandırılmıştır (Umay, 2003).

Somut veya soyut olgular arasındaki mantıksal bağlantılar matematiksel bilgidir. Duyu yoluyla alınanın ötesinde, akıl yürütme sonucu mantık zincirleri kurularak mantıksal-matematiksel bilgiler oluşur. Bir cismin kare olduğu, diğer bir cisimden büyük olduğu, uzaklığı-yakınlığı, yukarıdaaşağıda oluşu gibi ilişkilere dayalı bilgiler mantıksal-matematiksel bilgilerdir (Olgun \& Toluk Uçar, 2007). Matematiksel akıl yürütme yoluyla insanlar doğada her yerde bulunan sınırsız dizilişteki desenleri anlamaya ve yansitmaya gayret eder (English, 2004). Somut veya soyut olgular arasindaki mantıksal ilişki ve bağlantılara matematiksel bilgi denir. Duyu yoluyla alınanın ötesinde akıl yürütme sonucu mantıksal zincirler şeklinde mantıksal-matematiksel bilgiler oluşturulur. Matematikte akıl yürütme ile işlem önceliğini belirleme, işlemin yapısını sorgulayarak ve neyi, neden yaptığını bilerek işleme karar verme hem kalıcı hem de gelişmeye açık bir matematiğin oluşmasını sağlar. Matematiksel akıl yürütme, matematiksel bir bilgi ağının üzerinde ilerlerken yapılanır. Matematiği çok ilişkili fikirlerin bir ağı olarak görme akıl yürütme vurgusunun bir sonucuyken aynı zamanda daha ileri bir akıl yürütme için bir temeldir (Umay \& Kaf, 2005).

Çocuklar matematikle tanışmaya doğumdan itibaren başlar. Nesne devamlılığının ve temel neden sonuç ilişkilerinin kurulmasının basit matematik kavramlarının temelini oluşturmaktadır. $\mathrm{Bu}$ kavramların gelişimleri de yaşın ilerlemesiyle devam eder. Okul öncesi çocukları da problem çözme, sonuç çıkarma, bağlantılar kurma ve matematik dilini kullanmayı içeren matematiksel düşünceyi geliştirebilir ve temel düzeyde şekil, sayı, işlemler, ölçüm ve mekânda konum becerilerini kazanabilir. Erken çocukluk döneminde çocuklar için uygun matematik etkinlikleri ve oyunları planlarken çocukların matematiksel beceri seviyelerinin belirlenmesi, bireysel farklılıklara dikkat edilmesi, uygun materyal seçimi ve aile katılımına özen gösterilmelidir. Özellikle bebeklikten itibaren sağlanan zengin uyarıcılar beyin gelişimini desteklemektedir. Uyarıcı sağlanmayanlara oranla uyarıcı sağlanan bebek ve çocuklarda beceri gelişimi daha erken olmaktadır (Yalım, 2009).

\section{Erken Müzik Eğitimi}

Erken çocukluk döneminde sanat eğitimi, kişisel gelişimi ve yaratıcılığı desteklemek, estetik duyarlılık ile sanatsal yaratıma ilgiyi geliştirmek ve kültürel etkileşim sağlamak olmak üzere üç ana amaca hizmet etmelidir (Nikoltsos, 2000). Okul öncesi eğitim programları kapsamında hazırlanan 
sanat etkinlikleri, temelde yaratıcı düşünme ve estetik duyarlılı̆̆ geliştirmeyi amaçlayan etkinlikler olmalıdır (Aral, Kandır, \& Yaşar. 2002). Çizgi, renk, biçim, doku, ritm, hareket, müzik, dans ve rol yapma gibi sanat eğitimi faktörleri çocuğun eğlenerek öğrenme ve paylaşımda bulunmasını sağlar (Isenberg \& Jalongo, 2000). Müzik etkinlikleri ise çocukların dil gelişimi, ritimsel duyarlılık kazanmaları, kendilerini ifade edebilmeleri, sosyal uyum sağlama, güven ve başarı duygusunu kazanmaları açısından önemlidir (Aral vd., 2002). Çok eğlenceli ve keyifli olması sebebiyle müzik etkinlikleri okul öncesi eğitim kurumlarında zaman zaman eğlendirme, hoş vakit geçirme, boş zamanları doldurma amacıyla kullanılmakla birlikte müzik etkinlikleri, günlük öğretim planının ayrılmaz bir parçasıdır, planlama ve uygulamada sınıf öğretmeninin de aktif katılımıyla eğitim programının kazanımları dikkate alınarak tasarlanıp uygulanmalıdır. (Artan, 2001).

Müzik ile ilgili yapılan nörolojik araştırma bulgularına göre müzik eğitimi bilişsel gelişime katkı sağlamaktadır. Black tarafından 1997'de yapılan araştırma sonucu müzikal yaşantıların beyinde işitsel, görsel, bilişsel, duygusal ve motor sistemlerde temsil edildiği görülmüş̧ür. Ayrıca beynin işitsel korteksindeki bazı yapılar yalnızca müziksel uyarıcılara tepki vermektedir. Müzik, kan basıncı, nabız ve kasların elektriksel aktivitesinde doğrudan etkili olabilmektedir. Müziğin korteksteki beyin hücreleri arasındaki bağı güçlendirdiği Jensen'in 1998'deki araştırmasında bulunmuştur (Black \& Jensen'dan aktaran Ulusoy, Aytar, Akyol, Sübaş1, Ünver, \& Koç, 2014).

Erken yaşlarda verilmeye başlanılan müzik eğitimi, karmaşık muhakeme gerektiren üst düzey beyin fonksiyonlarını harekete geçirir, matematik, dil, uzamsal mantık gibi alanların gelişimine yardımcı olur. Müzik yoluyla hiperaktif ya da sinirli bir öğrenci yatışırken yorgun veya sessiz bir ögrenci harekete geçebilir. Bilimde ileri düzeyde olan ülkelerin eğitim politikalarında müzik ve sanata yer verildiği, çocukların müzik aleti çalması, korolar ve orkestralar gibi müzik topluluklarında yer alması için teşvik edildiği görülmektedir (Ulusoy vd., 2014).

Müzik eğitimi; bilim, sanat, dil gelişimi, sosyal beceriler ve matematik becerileri alanları ile yüksek oranda ilişkilendirilebilir. Müzik, bilim alanında hayvan ve bitki alemi, hava durumu ve mevsimler, insan sağlığı gibi bir çok konuda yardımcı bir disiplindir. Bu konuların öğretiminde canlandırma, dans, ilgili sesleri taklit, konu ile ilişkili şarkıları ve tekerlemeleri kullanarak öğrenmeye destek olunması mümkündür. Müzik ve görsel sanatlar ilk bakışta birbirinden ayrı gibi görünse de bu iki kavram aslen birbirine çok yakındır. Dinletilen bir şarkıya görsel öğeler eklendiğinde öğrenmenin kalıcılığı artacaktır. Müzikteki nüans, perde gibi özellikler resim ya da yoğurma etkinlikleriyle eşleştirilebilir. Dil gelişimi, bir müzik aleti çalmayı öğrenmeye çok benzer. Vücutta ilgili her şey hazırdır ancak öğrenme süreci gerekmektedir. Müzikteki ritim ve tonlamanın konuşmada da bulunması sebebiyle bu iki alan birbirinden ayrı düşünülemez. Müzik, hareket ve dil çocuğun kendi benliğini keşfetmesinde en büyük yardımcıdır. Çocuktaki olumlu benlik algısı onun sosyal çevresiyle etkileşimini yönlendirir. Çocuklar şekil, zaman, sayı gibi matematiksel kavramları da şarkı ve ritmik oyunlar, müzikli oyun ve canlandırma etkinlikleri ile öğrenebilirler (Ürfioğlu, 2000).

Müziksel yetenek, her çocukta var olan ve zaman içinde geliştirilebilen bir beceridir. Her çocuk, uygun ve doğru bir müzik eğitimi alarak tıpkı ana dilini öğrendiği gibi müzik yeteneği de geliştirebilir. Çocuk tekrarlı dinlemeler yoluyla ana dilini öğrendiği gibi aynı yolla müzik kulağını geliştirebilir (Suzuki, 1978). Suzuki metoduna göre küçük çocuklara piyano eğitimi verirken gözden, yani nota okumadan önce kulak eğitimine öncelik verilmelidir. Nota eğitimi çocuğun müzikal duyarlılı̆̆ı, çalma yeteneği ve hafızası geliştirildikten sonra verilmektedir. Çocuğun notay1 okuyabilmesi çok önemli olsa da çocuk başlangıçta nota öğrenmeye zorlanmamalıdır. Ana dil öğreniminde çocuğun önce konuşup sonra okumayı öğrendiği gibi, çocuk çalmayı öğrendikten sonra nota okumaya çalışmalıdır. Nota eğitiminin amacı çocuğun eserleri ezberlemesine yardımcı olmaktır (Kasap, 2005).

Milli Eğitim Bakanlığı (MEB) Okul öncesi eğitim programında bazı kazanımlar doğrudan müzik ile ilişkilendirilmiştir. Bunlar şu şekilde sıralanabilir:

Nesne veya varlıkları özelliklerine göre gruplar: Gruplama eylemini (doğal ses, müziksel ses gibi) sese göre yapmak,

Dinlediklerini/izlediklerini çeşitli yollarla ifade eder: Dinlenilenleri ve izlenilenleri müzik yoluyla ifade etmek, 
Kendini yaratıcı yollarla ifade eder: Müzik dinletilerine katılarak bu alanda yaşantı kazanmak,

Farklı kültürel özellikleri açıklar: Çeşitli etkinliklerde çocukların kendi ülkesinin kültürüne ait müzikleri ele almak,

Sanat eserlerinin değerini fark eder: Klasik müzik eserleri gibi sanat eserlerini öğrenme sürecinde kullanmak,

Müzik ve ritim eşliğinde hareket eder: Ritim çalışmalarında, müzik eşliğinde bedenini kullanmak; ellerini birbirine, dizlerine, göğsüne, kollarına vb. vurarak, parmak şaklatarak, ayaklarını yere vurarak ritme uydurmak,

Dinlenmenin önemini açıklar: Dinlenmeyi sadece uyumak olarak görmemek, müzik dinlemeyi bir dinlenme aracı olarak kullanmaktır (MEB, 2013).

Okul öncesi çağdaki piyano eğitimine başlama yaşı 4-6 yaş olarak kabul edilebilir (Uzsler, Gordon, \& Smith, 2000). Bu yaş grubundaki çocuklarla çalışırken piyano üzerinde uygulama süresi 15-20 dakikadan fazla olduğu takdirde çocukların ilgileri dağılabilir ve dersten sıkılabilirler. $\mathrm{Bu}$ noktada çocuğun yaşı ve ilgisi önemli rol oynamaktadır. Bu bakımdan, piyano öğretmeni, erken çocukluk dönemi piyano öğrencisinin öncelikle ilgisini çekmeli ve derse odaklanması ve eğlenmesini sağlamaya öncelik vermelidir (Gültek, 2010). Piyano eğitiminin çatısını nota (ses ve ritim unsurları ile) okumak oluşturur. Öğrenme hedefleri ayrıca klavyenin yapısını öğrenmek, teknik beceriler kazanmak ve ince motor becerileri geliştirmek üzerine kuruludur. Küçük çocuklarda nota okuma ise anahtarlar, dizek, ölçü, nota ismi ve süresi, sus, ifade sembolleri, tempo tutma gibi nota okumaya hazırlık çalışmalarını içerebilir (Thomas-Lee, 2003).

Erken piyano eğitiminde, dört-altı yaş grubundaki çocuklar için hazırlanan piyano çalmaya hazırlayıcı metotlar kullanılmaktadır. Bu metotlar, temel müziksel kavram ve becerileri kazandırmayı amaçlamaktadır. Metotlar incelendiğinde nota öğretiminde genellikle üç tür yaklaşım kullanıldığ1 görülmüştür (Faber \& Faber, 2007; Thompson, 2010; Bastien, 1987; Agay, 1992; Çevikkaya, 2012). Bunlar Orta do, aralıksal yaklaşım ve çoklu ton yaklaşımlarıdır. Orta do yaklaşımında iki elin başparmağı klavyenin tam ortasındaki do (Orta do) tuşunda bir arada iken diğer parmaklar çevresindeki beyaz tuşlara yerleştirilir. Orta do yaklaşımı ile öğretimde genellikle bu pozisyonda uzunca bir süre öğretime devam edilir. Aralıksal yaklaşımda (Intervallic Landmark) ise öğrenci piyano üzerinde kendine tüm do tuşları gibi bir işaret belirler ve bu işareti kullanarak istenilen notaya atlamalar yapar. Bu yaklaşım nota okumaya hazırlık çalışmalarında dizeksiz, şekilsel bir okuma kullanır. Yazımda nota aralıkları ve melodik yön dizeksiz olarak gösterilir. Çoklu ton (The Multiple Key) yaklaşımında ise öğrencilerin çok çeşitli pozisyon ve tonlarda çalmaları esastır. Öğrencilerden belirli bir ezgiyi Sol, Re, La, Mi gibi farklı nota pozisyonlarında da çalmaları istenir. Asıl hedef 12 tonun tamamında beşli (pentachord) pozisyona hâkim olmaktır. Ezgiyi farklı tonlarda çalmayı (transpoze) öğrenme ve tonun değiştiricilerini doğu kullanma alıştırma yoluyla geliştirilir. Yine de öğrencinin bazı çalışmalarda ezgiyi nota aralığı ve yönünü hesaplayarak çalabilmesi de beklenir. Piyano metotları geliştikçe zaman içinde çoklu ton yaklaşımı değişikliğe uğrayıp basitleşmiş, uzun süre do pozisyonunda kaldıktan sonra sol, fa ve diğer pozisyonlara geçilmiştir (Thomas-Lee, 2003).

Anasınıflarında piyanonun kullanımı hem müzik öğretmenlerinin yaygın olarak çalmayı bildiği bir çalgı olması, hem elektronik piyano ya da org gibi maliyeti daha uygun alternatiflerinin bulunması, hem de çocuklara sağladığı gelişimsel katkıları sebebiyle uygun bir seçim olabilir. Üniversitelerin Müzik Öğretmenliği Lisans Derslerinin içerikleri incelendiğinde de görülmektedir ki piyano eğitimi, müzik öğretmeni adaylarına okul çalgıları içerisinde en kapsamlı olarak verilen eğitimdir (Gazi Üniversitesi, 2019a, Marmara Üniversitesi, 2019a, Dokuz Eylül Üniversitesi, 2019a). Ayrıca, müzik etkinliklerinde piyanonun yalnız etkinliğe eşlik amaçlı değil, çocuklar tarafindan aktif olarak kullanılmasını sağlamak, çocuğu öğrenmenin merkezine alan yaklaşıma da uygun bir girişim olacaktır. Ayrıca klasik dizekli yazım ile nota eğitimine başlamak yerine, nota okumaya hazırlayıcı bir yaklaşım olan dizeksiz (off-staff) yazım daha iyi sonuç verebileceği için bu araştırmada hazırlanmış olunan piyano destekli müzik etkinliklerinde dizeksiz yazıma yer verilmiştir, piyanonun deney grubu tarafından aktif kullanımı sağlanmıştır. 
$\mathrm{Bu}$ araştırma bireysel çalgı eğitimi anlayışına bir alternatif olarak, küçük gruplarla çalışma yoluyla, temel müziksel kavramları ve becerileri öğrencinin etkinliklerde çalgıyı aktif kullanması yoluyla öğrenmesini sağlayacak bir eğitim programı sunması açısından önemlidir. Bu eğitim programında (Piyano Destekli Müzik Etkinlikleri) belirtilen avantajları sebebiyle piyano kullanılmıştır. Bu sayede mümkün olunacak en üst düzeyde öğreticilik ve işlevsellik hedeflenmiştir.

\section{Yöntem}

$\mathrm{Bu}$ araştırma deneysel bir çalışmadır. Ön-test son-test kontrol gruplu deneysel desen kullanılmıştır. Araştırmanın bağımlı değişkeni olan Piyano Destekli Müzik Etkinlikleri (PDME), MEB Okul Öncesi Eğitim Programında yer alan etkinlik planı şablonuna göre araştırmacı tarafından hazırlanmıştır. Ön-test sonuçlarına göre kontrol ve deney grupları oluşturulmuştur. Kontrol ve deney gruplarının oluşturulmasında ön-test sonuçları, cinsiyet, yaş, okul öncesi eğitim alma süresi, aile gibi demografik değişkenler dikkate alınmıştır. Ön-test ile grupların oluşturulmasının ardından deney grubuna araştırmacı tarafından PDME sekiz hafta boyunca uygulanmış, kontrol grubuna ise araştırmacı tarafından her hangi bir işlem uygulanmamıştır. Kontrol grubundaki çocuklar ana sınıfı öğretmenleri ile haftada iki gün müzik etkinlikleri işlemişlerdir. Bu etkinliklerde şarkı söyleme, ritim çalışmaları, müzikli oyunlar, hareket ve dans çalışmaları yapılmış, bir çalgı kullanılmamıştır. Uygulama, çocukların serbest zaman etkinlikleri kapsamında haftada 2 gün olmak üzere toplam 8 hafta olarak planlanmıştır. Her uygulamada, etkinlik süreleri yaklaşık 30 dakikadır. Çocukların odaklanması ve öğrenmelerini kolaylaştırmak adına 5-9 kişilik gruplarla çalışılmıştır.

Araştırmada PDME etkisini test edebilmek amacıyla hipotezler geliştirilmiştir. Bunlar;

" $\mathrm{H}^{\mathrm{o}}$ : Erken matematiksel akıl yürütme becerileri ön-test/son-test puan ortalamaları üzerinde deney grubu lehine anlamlı bir fark yoktur.",

" $\mathrm{H}^{1}$ : Erken matematiksel akıl yürütme becerileri ön-test/son-test puan ortalamaları üzerinde deney grubu lehine anlamlı bir fark vardır." olarak belirlenmiştir.

Araştırmanın pilot çalışmasında, veri toplama araçlarının uygulamasında ve deney grubu ile yapılmış olunan etkinliklerde çocuklara yapılmış olunan tüm işlemler için MEB'ndan araştırmacı tarafından gerekli izinler alınmıştır. Ayrıca çalışmaya katılan çocukların velilerinden çocuklarının araştırmaya katılabilmeleri için gerekli izni vermeleri veli izin formu ile istenmiştir.

\section{Çalışma Grubu}

$\mathrm{Bu}$ araştırmanın çalışma grubunu belirlemek için 2016-2017 eğitim öğretim y1lı bahar döneminde MEB Ankara ili Çankaya ilçe Milli Eğitim Müdürlüğ̈̈’ne bağlı ilköğretim okulları bünyesinden tesadüfi olarak iki adet ilkokul seçilmiştir. Bu ilkokullardan yine yansız olarak birer tane anasınıfı seçilmiştir. Çalışma grubunu oluşturan bu anasınıflarının müzik eğitiminde kullanılabilecek öğretim araç-gereçleri açısından benzer imkânlara sahip olmasına dikkat edilmiştir. Sınıflarda müzik öğretimi araç-gereci olarak tef, marakas gibi ritim çalgıları bulunmakta olup bağlama, gitar ve piyano gibi okul çalgıları müzik etkinliklerinde kullanılmamaktadır. Çalışma grubunu oluşturan çocukların daha önce piyano eğitimi almamış olmasına da dikkat edilmiştir. İki adet ilkokuldaki bu iki anasınıfından bir tanesinin deney grubunu, diğer anasınıfının ise kontrol grubunu oluşturmasına karar verilmiştir.

Çalışma grubunu oluşturan sınıflardan bir tanesi 17, diğeri 22 çocuk içermektedir. Ön-test, iki sınıfta eğitim alan toplam 39 çocuğa uygulanmıştır. Çalışma grubunun belirlenmesinde çocukların erken matematiksel akıl yürütme becerilerinin düşük ya da orta düzeyde olmasına, iyi düzeyde olanların araştırma dışında tutulmasına dikkat edilmiştir. Bu sebeple ön-test puanı yüksek olan deney grubundaki 1 çocuk ve kontrol grubundaki 2 çocuk çalışma grubundan çıkarılmıştır. Ön-test verilerine Mann-Whitney U testi uygulanmıştır. Ön-test sonucu deney grubundaki 16 çocuğa karşılık, kontrol grubundan orta ve düşük düzeyde test sonucuna sahip olan 4 çocuk daha çıkarılmıştır. $\mathrm{Bu}$ düzenlemeler sonucu 16 çocuk deney, 16 çocuk kontrol grubunda yer almış, toplam 32 çocukla çalışma yapılmıştır. Tablo 1'de deney ve kontrol grupları demografik değişkenlere göre dağılımı verilmiştir. 
Tablo 1. Deney ve Kontrol Gruplarının Demografik Değişkenlere Göre Dağılımı

\begin{tabular}{|c|c|c|c|c|c|}
\hline & & \multicolumn{2}{|c|}{ Kontrol Grubu $(\mathrm{N}=16)$} & \multicolumn{2}{|c|}{ Deney Grubu $(\mathrm{N}=16)$} \\
\hline & & $\mathbf{F}$ & $\%$ & $\mathbf{F}$ & $\%$ \\
\hline \multirow[t]{2}{*}{ Cinsiyet } & Kiz & 8 & 50 & 8 & 50 \\
\hline & Erkek & 8 & 50 & 8 & 50 \\
\hline \multirow[t]{2}{*}{ Ay Olarak İfade Edilen Yaş } & $60-65$ Ay & 7 & 43,7 & 7 & 43,7 \\
\hline & 66-72 Ay & 9 & 56,2 & 9 & 56,2 \\
\hline \multirow[t]{3}{*}{ Devam Ettiği Kurum Türü } & Resmi Ana Okulu & - & - & - & - \\
\hline & Özel Anaokulu & - & - & - & - \\
\hline & Ana Sinıfi & 16 & 100 & 16 & 100 \\
\hline \multirow[t]{2}{*}{ Kuruma Devam Durumu } & Yarım Gün & 16 & 100 & 16 & 100 \\
\hline & Tam Gün & - & - & - & - \\
\hline \multirow{4}{*}{$\begin{array}{l}\text { Okul Öncesi Eğitim Alma } \\
\text { Süresi }\end{array}$} & 3-6 Ay & - & - & - & - \\
\hline & 6 Ay-1 Y1l & 8 & 50 & 8 & 50 \\
\hline & $1-2 Y_{11}$ & 8 & 50 & 8 & 50 \\
\hline & 2-3 Yil & - & - & - & - \\
\hline \multirow[t]{3}{*}{ Anne Yaşı } & $24-29$ & 3 & 18,7 & 2 & 12,5 \\
\hline & $30-35$ & 5 & 31,2 & 6 & 37,5 \\
\hline & $36-41$ & 8 & 50 & 8 & 50 \\
\hline \multirow[t]{3}{*}{ Baba Yaşı } & $24-31$ & - & - & - & - \\
\hline & $32-37$ & 7 & 43,7 & 7 & 43,7 \\
\hline & $38-45$ & 9 & 56,2 & 9 & 56,2 \\
\hline \multirow[t]{3}{*}{ Anne Öğrenim Durumu } & İlköğretim & 6 & 37,5 & 6 & 37,5 \\
\hline & Ortaöğretim & 7 & 43,7 & 7 & 43,7 \\
\hline & Yükseköğretim & 3 & 18,7 & 3 & 18,7 \\
\hline \multirow[t]{3}{*}{ Baba Öğrenim Durumu } & İlköğretim & - & & - & \\
\hline & Ortaöğretim & 9 & 56,2 & 9 & 56,2 \\
\hline & Yükseköğretim & 7 & 43,7 & 7 & 43,7 \\
\hline
\end{tabular}

Tablo 1'de de görüldüğü üzere deney ve kontrol grupları oluşturulurken, çalışma grubunu oluşturan çocukların cinsiyeti, ay olarak ifade edilen yaşı, devam ettiği kurum türü ve kuruma yarım ya da tam gün devam etme durumu, toplamda ne kadar süre okul öncesi eğitim almış olduğu, annebabanın yaşları ve öğrenim durumları açısından da grupların eşit bir dağılım gösterilmesine dikkat edilmiştir. Deney ve kontrol gruplarının Erken Matematiksel Akıl Yürütme Becerileri Değerlendirme Aracı'nın alt boyutlarına göre düzenlenmesi için öncelikle grupların ön-test puan ortalamaları incelenmiştir. Veriler Tablo 2'de yer almaktadır.

Tablo 2. Deney ve Kontrol Gruplarının Ön-Test Puan Ortalamaları

\begin{tabular}{|c|c|c|c|c|c|c|}
\hline \multirow[b]{2}{*}{ Alt Boyutlar } & \multirow[b]{2}{*}{ Yönergeler } & \multicolumn{3}{|c|}{ KONTROL GRUBU } & \multicolumn{2}{|c|}{ DENEY G UBU } \\
\hline & & $\mathrm{N}$ & $\overline{\mathrm{x}}$ & SS & $\overline{\mathrm{x}}$ & ss \\
\hline \multirow[t]{3}{*}{ Ölçme-Tümevarım } & $\begin{array}{l}\text { Standart olmayan birimlerle ölçme ve } \\
\text { sonuçları karşılaştırma (Uzunluk ve } \\
\text { Ağırlık) }\end{array}$ & 16 & 3,66 & ,48 & 3,48 & ,49 \\
\hline & $\begin{array}{l}\text { Standart olmayan birimlerle ölçme ve } \\
\text { sonuçları karşılaştırma (Alan ve hacim) }\end{array}$ & 16 & 2,02 &, 57 & 2,41 & ,78 \\
\hline & Zaman sıralaması & 16 & 2,91 & ,79 & 3,02 & ,95 \\
\hline Ölçme- & Eldeki sonuçların doğruluğunu anlama & 16 & 1,35 & ,41 & 1,56 & ,64 \\
\hline Tümdengelim & Sözel karşılaştırma problemleri & 16 & 2,64 & 90 & 3,12 & 1,03 \\
\hline Veri Analizi ve & Şekillerin özelliklerini bilme & 16 & 2,02 &, 57 & 2,41 &, 78 \\
\hline Olasılık-Tümevarım & Grafik oluşturma & 16 & 2,85 & 1,06 & 2,50 & 1,15 \\
\hline $\begin{array}{l}\text { Veri Analizi ve } \\
\text { Olasillk- }\end{array}$ & $\begin{array}{l}\text { Resim inceleme ve resimdeki durumu } \\
\text { tahmin etme }\end{array}$ & 16 & 1,65 & ,61 & 1,76 &, 55 \\
\hline \multirow[t]{2}{*}{ Tümdengelim } & Grafik okuma ve sonuçlarını söyleme & 16 & 1,68 & 67 & 1,39 & ,61 \\
\hline & Olas1lık belirtme & 16 & 2,22 &, 72 & 2,38 & ,66 \\
\hline
\end{tabular}

Tablo 2'de deney ve kontrol gruplarının ön-test puan ortalamaları ve standart sapma değerleri görülmektedir. Puan ortalamalarının 1,3958 ile 3,6667 arasında değerlerde olduğu tespit edilmiştir. Deney ve kontrol gruplarının ön-test puan ortalamaları karşılaştırıldığında puan ortalamalarının iki 
grupta birbirlerine yakın değerler gösterdiği görülmektedir. Tablo 3'de deney ve kontrol gruplarının ön-test verilerinin hipotez testi olan Mann-Whitney U testine ait veriler yer almaktadır.

Tablo 3. Kontrol Grubu ile Deney Grubunun Ön-test Puanlarının Karşılaştırılması: İki Bağımsız Örnek için NonParametrik Mann-Whitney U Testi

\begin{tabular}{|c|c|c|c|c|c|c|}
\hline & Yönergeler & Grup & $\begin{array}{c}\text { Ortalama } \\
\text { Sirası }\end{array}$ & $\begin{array}{c}\text { Mann- } \\
\text { Whitney U } \\
\text { Değeri }\end{array}$ & $\begin{array}{l}\text { Anlamlılık } \\
\text { Seviyesi } \\
(\mathbf{p})\end{array}$ & Karar \\
\hline \multirow{3}{*}{$\begin{array}{l}\text { Ölçme Alanı } \\
\text { Tümevarım } \\
\text { Maddeleri }\end{array}$} & $\begin{array}{l}\text { Standart olmayan birimlerle ölçme ve } \\
\text { sonuçları karşılaştırma (Uzunluk ve } \\
\text { Ağırlık) }\end{array}$ & $\begin{array}{l}\text { Kontrol } \\
\text { Deney }\end{array}$ & $\begin{array}{l}17,94 \\
15,06\end{array}$ & 105,00 & 0,402 & $\begin{array}{c}\text { Ho } \\
\text { Kabul }\end{array}$ \\
\hline & $\begin{array}{l}\text { Standart olmayan birimlerle ölçme ve } \\
\text { sonuçları karşlaştırma (Alan ve hacim) }\end{array}$ & $\begin{array}{l}\text { Kontrol } \\
\text { Deney }\end{array}$ & $\begin{array}{l}14.00 \\
19,00\end{array}$ & 168,00 & 0,138 & $\begin{array}{c}\text { Ho } \\
\text { Kabul }\end{array}$ \\
\hline & Zaman siralamas1 & $\begin{array}{l}\text { Kontrol } \\
\text { Deney }\end{array}$ & $\begin{array}{l}16,06 \\
16,94 \\
\end{array}$ & 135,00 & 0,809 & $\begin{array}{c}\text { Ho } \\
\text { Kabul }\end{array}$ \\
\hline \multirow{2}{*}{$\begin{array}{l}\text { Ölçme Alanı } \\
\text { Tümdengelim } \\
\text { Maddeleri }\end{array}$} & Eldeki sonuçların doğruluğunu anlama & $\begin{array}{l}\text { Kontrol } \\
\text { Deney }\end{array}$ & $\begin{array}{l}15,22 \\
17,78 \\
\end{array}$ & 148,50 & 0,445 & $\begin{array}{c}\text { Ho } \\
\text { Kabul }\end{array}$ \\
\hline & Sözel karşılaştırma problemleri & $\begin{array}{l}\text { Kontrol } \\
\text { Deney }\end{array}$ & $\begin{array}{l}14,53 \\
18,47 \\
\end{array}$ & 159,50 & 0,239 & $\begin{array}{c}\text { Ho } \\
\text { Kabul }\end{array}$ \\
\hline \multirow{2}{*}{$\begin{array}{l}\text { Veri Analizi ve } \\
\text { Olasılık Alanı } \\
\text { Tümevarım } \\
\text { Maddeleri }\end{array}$} & Şekillerin özelliklerini bilme & $\begin{array}{l}\text { Kontrol } \\
\text { Deney }\end{array}$ & $\begin{array}{l}14,00 \\
19,00 \\
\end{array}$ & 168,00 & 0,138 & $\begin{array}{c}\text { Ho } \\
\text { Kabul }\end{array}$ \\
\hline & Grafik oluşturma & $\begin{array}{l}\text { Kontrol } \\
\text { Deney } \\
\end{array}$ & $\begin{array}{l}18,06 \\
14,94 \\
\end{array}$ & 103,00 & 0,361 & $\begin{array}{c}\text { Ho } \\
\text { Kabul }\end{array}$ \\
\hline \multirow{3}{*}{$\begin{array}{l}\text { Veri Analizi ve } \\
\text { Olasılık Alanı } \\
\text { Tümdengelim } \\
\text { Maddeleri }\end{array}$} & $\begin{array}{l}\text { Resim inceleme ve resimdeki durumu } \\
\text { tahmin etme }\end{array}$ & $\begin{array}{l}\text { Kontrol } \\
\text { Deney }\end{array}$ & $\begin{array}{l}15,69 \\
17,31\end{array}$ & 141,00 & 0,642 & $\begin{array}{c}\text { Ho } \\
\text { Kabul }\end{array}$ \\
\hline & Grafik okuma ve sonuçlarını söyleme & $\begin{array}{l}\text { Kontrol } \\
\text { Deney }\end{array}$ & $\begin{array}{l}18,47 \\
14,53\end{array}$ & 96,50 & 0,239 & $\begin{array}{c}\text { Ho } \\
\text { Kabul }\end{array}$ \\
\hline & Olasilik belirtme & $\begin{array}{l}\text { Kontrol } \\
\text { Deney }\end{array}$ & $\begin{array}{l}15,62 \\
17,38 \\
\end{array}$ & 142,00 & 0,616 & $\begin{array}{c}\text { Ho } \\
\text { Kabul }\end{array}$ \\
\hline
\end{tabular}

Tablo 3'de deney ve kontrol gruplarının ön-test sonuçları incelendiğinde ölçeğe ait alt boyutlardaki anlamlılık seviyelerinin 0,138 ile 0,809 arasında olduğu ortaya çıkmaktadır. Erken matematiksel akı1 yürütmenin alt boyutları olan "Ölçme: tümevarım ve tümdengelim" ile "Veri analizi olasılık: tümevarım ve tümdengelim" alanları için tüm alt faktörlerde deney ve kontrol gruplarının eşitliğinin sağlandığı " $\mathrm{H}^{\mathrm{o}}$ ”ı kabulü ile tespit edilmiştir.

\section{Veri Toplama Araci}

$\mathrm{Bu}$ araştırmada veri toplama aracı olarak Erken Matematiksel Becerileri Değerlendirme Aracı (EMAYBDA), (Ergül, 2014, s. 165) kullanılmıştır. Erken matematiksel akıl yürütme becerileri ile ilgili ülkemizde ilk çalışma Ergül tarafından 2014'de yapılmış, araştırma kapsamında bu araştırmada da kullanılmış olunan EMAYBDA geliştirilmiştir. Araştırmada çocukların ölçme ve veri analiziolasılık alanlarındaki matematiksel akıl yürütme becerilerini belirlemek hedeflenmiştir. Ölçeğin geçerlilik-güvenilirlik çalışmasının örneklemi, Ankara ili merkez ilçelerinde MEB'na bağlı anasınıfi, bağımsız anaokulu ve özel kreş, gündüz bakımevi ve anaokulundan tesadüfi örnekleme yoluyla seçilmiştir. Araştırmanın geçerlilik-güvenilirlik çalışmasında 60-74 aylık yaş grubundaki normal gelişim gösteren toplam 90 çocukla yapılmıştır. 50 çocuk ön uygulamada, 40 çocuk ise test-tekrar test güvenilirliği çalışmasında yer almıştır. Veriler araştırmacı tarafindan geliştirilen, bütüncül rubrik türündeki "EMAYBDA" ve "Çocuk Bilgi Formu" ile elde edilmiştir. Araştırma sonucunda; geliştirilen aracın geçerli ve güvenilir olduğu bulunmuştur. Toplam 40 sorudan oluşan aracın uygulaması çocukla bireysel görüşme şeklinde gerçekleştirilmektedir. 28 soru resimler, 9 soru çeşitli materyaller ile ve geri kalan 3 soru da herhangi bir materyal kullanmaksızın yalnızca sözel olarak çocuklara yöneltilmiştir. Toplam 40 sorudan oluşan aracın 21 sorusu ölçme, 19 sorusu ise veri analizi-olasılık alanında yer almaktadır. Tümevarımsal akıl yürütmede 21, tümdengelimsel akıl yürütmede ise 19 soru bulunmaktadır. Tümevarım türünde ölçme alt boyutunda standart olmayan uzunluk ve ağırlık birimleriyle ölçme ve sonuç karşılaştırma alanlarında altı soru, alan ve hacim birimleriyle ölçme ve sonuç karşılaştırma alanlarında altı soru, zaman sıralaması ile ilgili 3 soru bulunmaktadır. Tümdengelim türünde ölçme alt boyutunda eldeki sonuçların doğruluğunu anlama alanında 3 soru, sözel karşılaştırma problemleri alanında 3 soru bulunmaktadır. Tümevarım türünde veri analizi ve olasılık alt boyutunda şekillerin özelliklerini bilme alanında 3 soru, grafik oluşturma alanında 3 soru 
bulunmaktadır. Tümdengelim türünde veri analizi ve olasılık alt boyutunda resim inceleme ve resimdeki durumu tahmin etme alanında 4 soru, grafik okuma ve sonuçlarını söyleme ile ilgili 4 soru, olasılık belirleme ile ilgili 6 soru yer almaktadır. Çocukların ölçeğe verebileceği cevapların nedenlerine ilişkin olarak, çocukların yapabilecekleri yorumlar tahmin edilmiş ve ölçütler genel olarak belirlenmiş, 0-5 arasında bir değer verilerek puanlanmıştır (Ergül, 2014).

\section{Piyano Destekli Müzik Etkinlikleri (PDME)}

Araştırmacı tarafından hazırlanmış olunan PDME okul öncesi dönemdeki 5-6 yaş çocuklarına müzik eğitimini piyano desteği ile vermeyi amaçlamaktadır. Hazırlık aşamasında öncelikle alan-yazı taraması yapılarak mevcut erken çocukluk dönemi piyano öğretimi metotları ve öğretmen rehber kitapları incelenerek bu kaynaklar doğrultusunda kazanım ve göstergelerin belirlenmesi için ön çalışma yapılmıştır. Etkinliklerin hazırlık sürecinde çocukların bireysel farklılıkları ve gelişimsel özellikleri göz önünde bulundurmuş, öğretimde basitten karmaşığa, somuttan soyuta ilkeleri dikkate alınmıştır. Belirlenen kazanım ve göstergeler doğrultusunda hazırlanan 20 dakika süreli etkinlik planları haftada iki gün olmak üzere sekiz haftalık olarak düzenlenmiştir. Son şekli verilen etkinliklerin geçerliliği için öncelikle eğitim programları ve öğretim alanındaki bir uzmandan etkinlik kazanım ve göstergeleri ile ilgili görüşleri alınmıştır. Ardından müzik öğretmenliği, okul öncesi eğitimi ve çocuk gelişimi alanlarından doktora derecesine sahip yedi uzmanın görüşlerine başvurulmuştur. Toplam 8 uzman ile görüşme yapılmıştır. Uzmanlardan; etkinlikleri amacına uygunluk, açıklık ve anlaşılırlık açısından eleştirmeleri, gerekli gördükleri durumlarda etkinliklerin değiştirilmesi, düzeltilmesi ve çıkartılması ile ilgili görüşlerini belirtmeleri istenmiştir. Uzmanlardan etkinlikleri değerlendirirken öncelikle kazanım ve göstergelerinin PDME'ni kapsama durumu ve 5-6 yaş grubundaki çocukların gelişim düzeylerini dikkate almaları talep edilmiştir. Ayrıca uzmanlar etkinlik planlarını kazanımlara uygun ve çocukların ilgisini çekecek nitelikte olması, yeterli somut deneyim sağlaması, etkinlik süresinin yeterliliği, kullanılacak materyallerin amaca uygunluğu, etkinlik sırasında çocuklara verilen yönergelerin açıklığı, bir etkinlikten diğer etkinliğe geçişlerin uygunluğu, etkinliklerin kendi içinde bütünlük göstermesi açısından da irdelemesi istenmiştir. Hazırlanmış olunan etkinliklerin uzman görüşleriyle güvenilirliği sağlandıktan sonra MEB Çankaya ilçesindeki bir ilkokula bağlı bir anasınıfının öğrencilerine araştırmacı tarafından bu etkinliklerin pilot uygulaması yapılmıştır. Araştırmanın geçerlilik çalışması olan bu uygulama, haftada 2 gün, 20 dakika olmak üzere toplam 8 hafta sürmüştür. Pilot uygulama toplam 25 çocuğa yapılmıştır. Etkinliklerin uygulanmasını kolaylaştırmak ve öğrenmede kalıcılığını arttırmak amacıyla çocukların etkinliklere 5-8 kişilik gruplar halinde katılmasına karar verilmiştir. Pilot uygulama sonucunda kazanım ve göstergeler, etkinlik planları, öğrenme araçları, etkinlik işleniş süreci ve değerlendirme durumları yeniden irdelenerek etkinliklere son şekli verilmiştir.

PDME kazanım ve göstergeleri, uygulanmakta olunan Milli Eğitim Bakanlığı Okul Öncesi Eğitim Programında yer almamakta olup, söz konusu müzik etkinlikleri için özel olarak geliştirilmiştir. Sekiz haftalık etkinlik planı için toplam 7 adet kazanım belirlenmiştir. Bu kazanımlar çocuklara temel müzik kavramlarını ve becerilerini öğretmenin yanı sıra piyano eğitimi ile ilgili kazanımlar da içermektedir. Kazanım ve göstergeleri şu şekilde listelenmiştir:

1. Piyanoyu oluşturan parçaları tanır.

1. Piyanoda klavyeyi gösterir.

2. Klavye tuşlarının renklerini söyler.

3. Piyano pedallarını gösterir.

4. Kaç pedal olduğunu söyler.

2. Klavye tuşlarını kullanarak farklı sesler üretir.

1. Klavyeyi kullanarak kısa ve uzun sesler çalar.

2. Klavyeyi kullanarak ince ve kalın sesler çalar.

3. Piyanodaki tuş dizilimi özelliklerini kavrar.

1. İkili siyah tuş gruplarını gösterir. 
2. Üçlü siyah tuş gruplarını gösterir.

3. Siyah tuşları çalar.

4. Piyanoda do tuşlarının ikili siyah tuş grubunun solunda kaldığını söyler.

5. Piyanoda do tuşlarını çalar.

4. Parmak numaraları ile el parmaklarını ilişkilendirir.

1. Öğretmenin söylediği parmak numarasının hangi parmağa ait olduğunu gösterir.

2. Verilen çalışma parçasındaki parmak numarasını doğru parmakla çalar.

5. Notalar ile piyano tuşlarını ilişkilendirir.

1. Kalınlaşan seslerin notasının daha aşağıda yazıldığını söyler.

2. İncelen seslerin notasının daha yukarıda yazıldığını söyler.

3. Verilen çalışma parçasında notaları gösterir.

4. Bir vuruşluk notayı gösterir.

5. Bir vuruşluk notanın şekilsel özelliklerini söyler.

6. Verilen çalışma parçasında yer alan bir vuruşluk notaları doğru süre değeriyle çalar.

7. Verilen çalışma parçasında sapı yukarıda olan notaları piyanoda sağ el ile çalar.

8. Verilen çalışma parçasında sapı aşağıda olan notaları piyanoda sol el ile çalar.

6. Gürlük (nüans) simgeleri ile sesin özelliklerini ilişkilendirir.

1. Gürlük kelimesinin sesin kısıklık ya da yüksekliği olduğunu söyler.

2. "Forte" (f) simgesinden sonraki notaların yüksek sesli olduğunu söyler.

3. Verilen çalışma parçasında "Forte" simgesini (f) gösterir.

4. Verilen çalışma parçasında (f) simgesi olan notaları yüksek sesle çalar.

5. "Piano" (p) simgesinden sonraki notaların kısık sesli olduğunu söyler.

6. Verilen çalışma parçasında "Piano" simgesini (p) gösterir.

7. Verilen çalışma parçasında (p) simgesinden sonra gelen notaları kısık sesle çalar.

\section{Verilerin Analizi}

Verilerin analizi SPSS 16.0 for Windows programıyla yapılmıştır. Çalışma grubunu oluşturan çocuk sayısının az (32) olması sebebiyle parametrik olmayan hipotez testleriyle sonuçların analizine karar verilmiştir. Ön-test uygulamasının ardından deney grubu çocuklarıyla, kontrol grubu çocuklarının erken matematiksel akıl yürütme becerileri ön-test alt boyut puanları "İki Bağımsız Örnek İçin Non-Parametric Mann-Whitney U Testi ile analiz edilmiş, deney ve kontrol gruplarının öntest puanları eşit tutulmuş, aritmetik ortalama ve standart sapma değerleri hesaplanmıştır. Bağımsız değişkenin deney grubuna uygulanmasının ardından aynı test son-test verilerine de uygulanmıştır. PDME'nin çocukların erken matematiksel akıl yürütme becerilerinin alt boyutlarını etkileyip etkilemediğini sınamak için, deney ve kontrol gruplarının son-test puan ortalamaları arasında anlamlı düzeyde bir farklılaşma olup olmadığını saptamak amacıyla Eşleştirilmiş Örnekler İçin NonParametric Wilcoxon İşaretli Sıralar Testi uygulanmıştır.

\section{Bulgular}

Anasınıfına devam eden 5-6 yaş grubundaki çocukların erken matematiksel akıl yürütme becerilerine PDME'nin etkisini tespit etmek amacıyla yapılan bu araştırma sonucunda elde edilen veriler bu bölümde verilmiştir. Bulgular tablolar halinde gösterildikten sonra irdelenip yorumlanmıştır. Veri analizi için ilk olarak deney grubunun puan ortalamalarına ait artışın ön-test verileriyle bir 
farklılık gösterip göstermediğini irdelemek amaciyla Tablo 4'te ön-test ve son-teste ait puan ortalamaları sunulmuştur.

Tablo 4: Deney ve Kontrol Gruplarının Ön-test Son-test Puan Ortalamaları

\begin{tabular}{|c|c|c|c|c|c|c|c|}
\hline \multirow{2}{*}{$\begin{array}{l}\text { Alt } \\
\text { Boyutlar }\end{array}$} & & \multirow[b]{2}{*}{ Yönergeler } & & \multicolumn{2}{|c|}{ Ön-Test } & \multicolumn{2}{|c|}{ Son-Test } \\
\hline & & & $\mathrm{N}$ & Kontrol & Deney & Kontrol & Deney \\
\hline \multirow{5}{*}{ 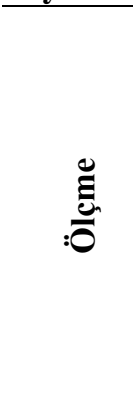 } & \multirow{3}{*}{ Tümevarım } & $\begin{array}{l}\text { Standart olmayan birimlerle ölçme ve } \\
\text { sonuçları karşılaştırma (Uzunluk ve } \\
\text { Ağırlık) }\end{array}$ & 16 & 3,66 & 3,48 & 3,84 & 4,28 \\
\hline & & $\begin{array}{l}\text { Standart olmayan birimlerle ölçme ve } \\
\text { sonuçları karşılaştırma (Alan ve } \\
\text { hacim) }\end{array}$ & 16 & 2,02 & 2,41 & 2,52 & 3,43 \\
\hline & & Zaman sıralaması & 16 & 2,91 & 3,02 & 3,33 & 3,89 \\
\hline & \multirow{2}{*}{ Tümdengelim } & Eldeki sonuçların doğruluğunu anlama & 16 & 1,35 & 1,56 & 1,77 & 2,02 \\
\hline & & Sözel karşılaştırma problemleri & 16 & 2,64 & 3,12 & 3,14 & 3,87 \\
\hline \multirow{5}{*}{ 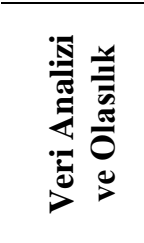 } & \multirow{2}{*}{ Tümevarım } & Şekillerin özelliklerini bilme & 16 & 2,02 & 2,41 & 2,52 & 3,43 \\
\hline & & Grafik oluşturma & 16 & 2,85 & 2,50 & 3,29 & 3,60 \\
\hline & \multirow{3}{*}{ Tümdengelim } & $\begin{array}{l}\text { Resim inceleme ve resim eki durumu } \\
\text { tahmin etme }\end{array}$ & 16 & 1,65 & 1,76 & 1,98 & 2,35 \\
\hline & & Grafik okuma ve sonuçlarını söyleme & 16 & 1,68 & 1,39 & 1,93 & 1,91 \\
\hline & & Olasıllk belirtme & 16 & 2,22 & 2,38 & 2,57 & 3,98 \\
\hline
\end{tabular}

Çalışma grubunun erken matematiksel akıl yürütme becerilerine ait son-test puan ortalamaları 1,77 ile 3,84 arasındadır. Ön-test ve son-test puan ortalamaları incelendiğinde öncelikle her iki grupta da son-test verilerine ait puanlarda artış görülmektedir. Bu sonuç iki grubun da erken matematiksel akıl yürüme becerilerinde bir miktar ilerleme kaydettiğini göstermektedir. Yine de deney grubunun öntest ve son-test puan ortalamaları kontrol grubuyla karşılaştırıldığında testler arasındaki farkın deney grubunda daha fazla olduğu görülmektedir.

Deney ve kontrol gruplarının oluşturulma sürecinde ön-test verilerine uygulanan MannWhitney U testi sonuçları dikkate alınmış, her iki grupta da Hipotez 0 kabul görmüştür (Bkz. Tablo 3). Aynı test çocukların son-test verilerine de uygulanmıştır. Teste ilişkin veriler Tablo 5'tedir.

Tablo 5. Kontrol Grubu İle Deney Grubunun Son-test Puanlarının Karşılaştııılması: İki Bağımsız Örnek için Non-Parametrik Mann-Whitney U Testi

\begin{tabular}{|c|c|c|c|c|c|c|c|}
\hline \multicolumn{2}{|c|}{ Alt Boyutlar } & \multirow{2}{*}{$\begin{array}{l}\text { Yönergeler } \\
\text { Standart olmayan birimlerle } \\
\text { ölçme ve sonuçları karşıllaştırma } \\
\text { (Uzunluk ve Ağırlık) }\end{array}$} & \multirow{2}{*}{\begin{tabular}{l}
\multicolumn{1}{c}{ Grup } \\
Kontrol \\
Deney
\end{tabular}} & \multirow{2}{*}{$\begin{array}{c}\begin{array}{c}\text { Sira } \\
\text { Ort }\end{array} \\
11,19 \\
21,81\end{array}$} & \multirow{2}{*}{$\begin{array}{c}\mathbf{U} \\
213,00\end{array}$} & \multirow{2}{*}{$\frac{\mathbf{p}}{0,001^{*}}$} & \multirow{2}{*}{$\begin{array}{c}\text { Karar } \\
\mathrm{H}_{0} \\
\text { Red }\end{array}$} \\
\hline \multirow{5}{*}{$\stackrel{\stackrel{\Xi}{\Xi}}{:}$} & \multirow{3}{*}{ 章 } & & & & & & \\
\hline & & $\begin{array}{l}\text { Standart olmayan birimlerle } \\
\text { ölçme ve sonuçları karşılaştırma } \\
\text { (Alan ve hacim) }\end{array}$ & $\begin{array}{l}\text { Kontrol } \\
\text { Deney }\end{array}$ & $\begin{array}{l}10,75 \\
22,25\end{array}$ & 220,00 & $0,000 *$ & $\begin{array}{l}\mathrm{H}_{0} \\
\text { Red }\end{array}$ \\
\hline & & Zaman sıralaması & $\begin{array}{l}\text { Kontrol } \\
\text { Deney }\end{array}$ & $\begin{array}{l}12,06 \\
20,94 \\
\end{array}$ & 199,00 & $0,007 *$ & $\begin{array}{c}\mathrm{H}_{0} \\
\text { Red } \\
\end{array}$ \\
\hline & \multirow{2}{*}{ 离 } & $\begin{array}{l}\text { Eldeki sonuçların doğruluğunu } \\
\text { anlama }\end{array}$ & $\begin{array}{l}\text { Kontrol } \\
\text { Deney }\end{array}$ & $\begin{array}{l}15,06 \\
17,94 \\
\end{array}$ & 151,00 & 0,402 & $\begin{array}{c}\mathrm{H}_{0} \\
\text { Kabul }\end{array}$ \\
\hline & & Sözel karşılaş̧ırma problemleri & $\begin{array}{l}\text { Kontrol } \\
\text { Deney }\end{array}$ & $\begin{array}{l}12,81 \\
20,19\end{array}$ & 187,00 & $0,026^{*}$ & $\begin{array}{c}\mathrm{H}_{0} \\
\text { Red }\end{array}$ \\
\hline \multirow{5}{*}{ 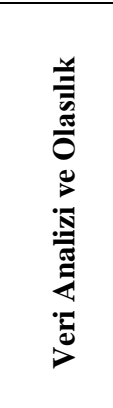 } & \multirow{2}{*}{ 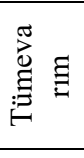 } & Şekillerin özelliklerini bilme & $\begin{array}{l}\text { Kontrol } \\
\text { Deney }\end{array}$ & $\begin{array}{l}10,75 \\
22,25\end{array}$ & 220,00 & $0,000 *$ & $\begin{array}{l}\mathrm{H}_{0} \\
\text { Red }\end{array}$ \\
\hline & & Grafik oluşturma & $\begin{array}{l}\text { Kontrol } \\
\text { Deney }\end{array}$ & $\begin{array}{l}16,00 \\
17,00 \\
\end{array}$ & 136,00 & 0,780 & $\begin{array}{c}\mathrm{H}_{0} \\
\text { Kabul } \\
\end{array}$ \\
\hline & \multirow{3}{*}{$\begin{array}{l}: \Xi \\
D \\
0 \\
0 \\
0 \\
: \Xi \\
:\end{array}$} & $\begin{array}{l}\text { Resim inceleme ve resimdeki } \\
\text { durumu tahmin etme }\end{array}$ & $\begin{array}{l}\text { Kontrol } \\
\text { Deney }\end{array}$ & $\begin{array}{l}14,03 \\
18,97\end{array}$ & 167,50 & 0,138 & $\begin{array}{c}\mathrm{H}_{0} \\
\text { Kabul }\end{array}$ \\
\hline & & $\begin{array}{l}\text { Grafik okuma ve sonuçlarını } \\
\text { söyleme }\end{array}$ & $\begin{array}{l}\text { Kontrol } \\
\text { Deney }\end{array}$ & $\begin{array}{l}16,66 \\
16,34 \\
\end{array}$ & 125,50 & 0,926 & $\begin{array}{c}\mathrm{H}_{0} \\
\text { Kabul }\end{array}$ \\
\hline & & Olasilık belirtme & $\begin{array}{l}\text { Kontrol } \\
\text { Deney }\end{array}$ & $\begin{array}{l}10,09 \\
22,91\end{array}$ & 230,50 & $0,000 *$ & $\begin{array}{l}\mathrm{H}_{0} \\
\text { Red }\end{array}$ \\
\hline
\end{tabular}


Kontrol ve deney gruplarının son-test puanları incelendiğinde on maddenin altısında $\mathrm{H}^{\mathrm{o}}$ Red sonucuyla deney grubu lehine anlamlı fark görülmektedir. Bu maddeler ölçme-tümevarım alt boyutu için standart olmayan birimlerle uzunluk ve ağırlı $(p=0,001)$ ile alan ve hacim $(p=0,00)$ ölçme ve sonuçları karşılaştırma ve zaman sıralaması $(\mathrm{p}=0,007)$; ölçme tümdengelim için sözel karşılaştırma problemleri $(\mathrm{p}=0,026)$; veri analizi olasılık-tümevarım alanında şekillerin özelliklerini bilme $(\mathrm{p}=0,00)$; veri analizi olasılık-tümdengelim alanında olasılık belirtmedir $(\mathrm{p}=0,00)$.

Sonraki aşamada erken matematiksel akıl yürütme becerileri "ölçme" alt boyutunda deney grubu lehine anlamlı bir fark görülüp görülmediğine bakılmıştır. Bunun için öncelikle kontrol grubunun son-test verileri bu gruptaki çocukların rutin eğitim süreçleri içerisinde gösterdiği gelişmeyi irdelemek için ön-test verileri ile karşılaştırılmıştır. Tablo 6'da yer alan bu analiz ile kontrol grubundaki çocukların erken matematiksel akıl yürütmenin hangi alanlarında ilerleme kat ettiği incelenmiştir.

Tablo 6. Kontrol Grubu Ön-test Puanları ile Son-test Puanları Arasındaki Farkın Analizi: Eşleştirilmiş Örnekler İçin Non-parametrik Wilcoxon İşaretli Suralar Testi

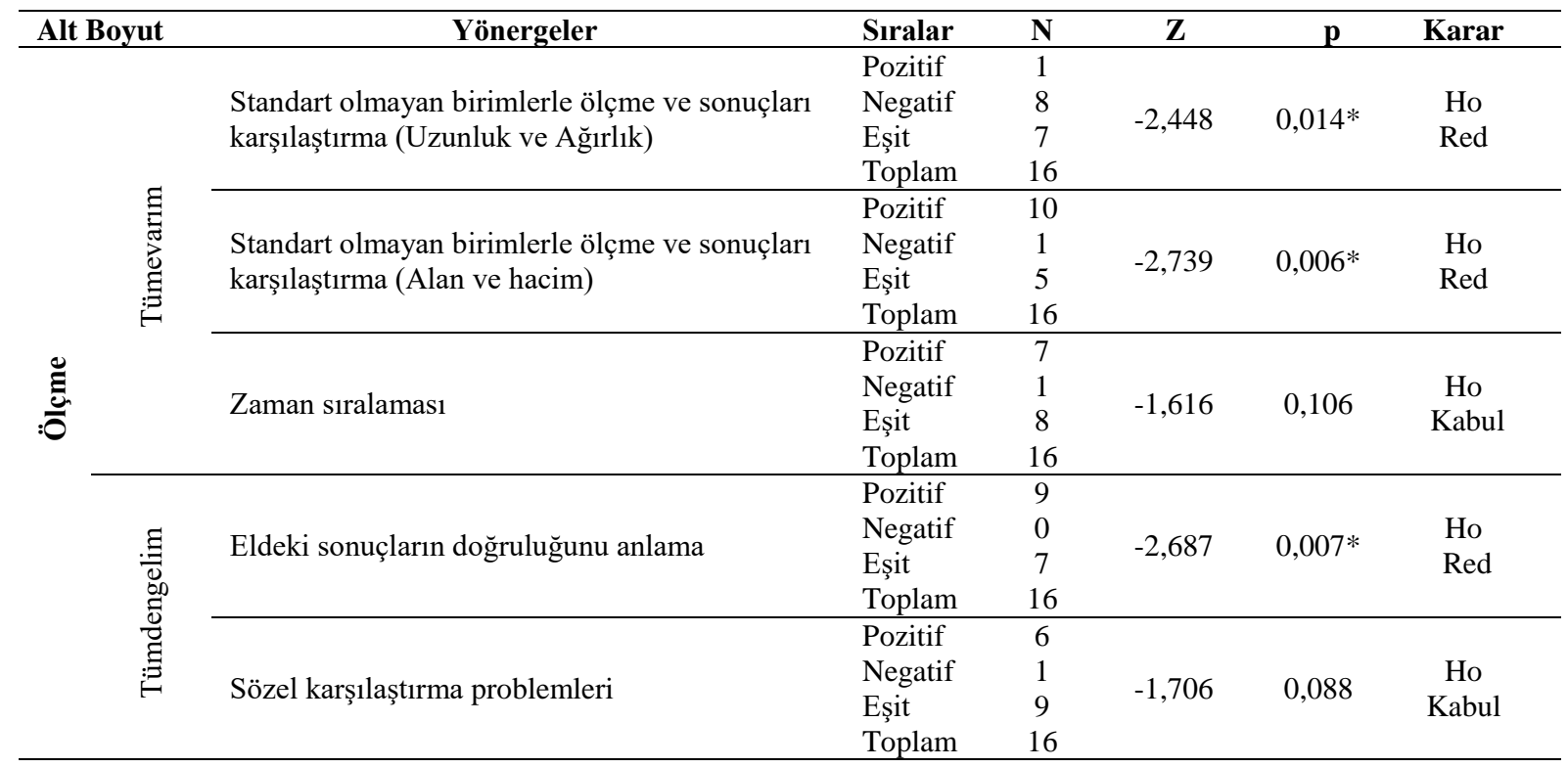

Kontrol grubunun son-test verilerinin ön-test ile karşılaştırılması sonucu erken matematiksel akıl yürütme becerileri ölçme alt boyutuna ait standart olmayan birimlerle uzunluk ve ağırlık $(\mathrm{p}=0,014)$ ile alan ve hacim $(\mathrm{p}=0,06)$ ölçme ve sonuçları karşılaştırma, eldeki sonuçların doğruluğunu anlama $(\mathrm{p}=0,007)$ yönergelerinde anlamlı fark görülmüş ve hipotez O'in reddine karar verilmiştir.

Deney grubunun erken matematiksel akıl yürütme becerileri, ölçme alt boyutuna ilişkin gösterdiği gelişme son-test verilerinin ön-test verileri ile karşılaştırılması yoluyla yapılmıştır. $\mathrm{Bu}$ amaçla Tablo 7'de deney grubu ön-test ve son-test verilerinin Wilcoxon İşaretli Sıralar Testi sonuçlarına yer verilmiştir. 
Tablo 7. Deney Grubu Ön-test Puanları ile Son-test Puanları Arasındaki Farkın Analizi: Eşleştirilmiş Örnekler İçin Non-parametrik Wilcoxon İşaretli Sıralar Testi

\begin{tabular}{|c|c|c|c|c|c|c|c|}
\hline \multicolumn{2}{|c|}{ Alt Boyut: } & \multicolumn{2}{|l|}{ Yönergeler } & $\begin{array}{l}\mathbf{N} \\
16\end{array}$ & $\mathbf{Z}$ & $\mathbf{p}$ & Karar \\
\hline \multirow{5}{*}{ : } & \multirow{3}{*}{ 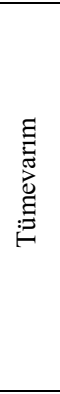 } & $\begin{array}{l}\text { Standart olmayan birimlerle ölçme ve } \\
\text { sonuçları karşılaştırma (Uzunluk ve } \\
\text { Ağırlık) }\end{array}$ & $\begin{array}{l}\text { Pozitif } \\
\text { Negatif } \\
\text { Eşit } \\
\text { Toplam }\end{array}$ & $\begin{array}{c}16 \\
0 \\
0 \\
16 \\
\end{array}$ & $-3,524$ & $0,000 *$ & $\begin{array}{c}\mathrm{H}_{0} \\
\text { Red }\end{array}$ \\
\hline & & $\begin{array}{l}\text { Standart olmayan birimlerle ölçme ve } \\
\text { sosnuçları karşllaştırma (Alan ve hacim) }\end{array}$ & $\begin{array}{l}\text { Pozitif } \\
\text { Negatif } \\
\text { Eşit } \\
\text { Toplam } \\
\end{array}$ & $\begin{array}{c}14 \\
0 \\
2 \\
16 \\
\end{array}$ & $-3,310$ & $0,001 *$ & $\begin{array}{l}\mathrm{H}_{0} \\
\text { Red }\end{array}$ \\
\hline & & Zaman sıralaması & $\begin{array}{l}\text { Pozitif } \\
\text { Negatif } \\
\text { Eşit } \\
\text { Toplam } \\
\end{array}$ & $\begin{array}{c}12 \\
0 \\
4 \\
16 \\
\end{array}$ & $-3,077$ & $0,002 *$ & $\begin{array}{l}\mathrm{H}_{0} \\
\text { Red }\end{array}$ \\
\hline & \multirow{2}{*}{ 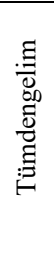 } & Eldeki sonuçların doğruluğunu anlama & $\begin{array}{l}\text { Pozitif } \\
\text { Negatif } \\
\text { Eşit } \\
\text { Toplam } \\
\end{array}$ & $\begin{array}{c}9 \\
1 \\
6 \\
16 \\
\end{array}$ & $-2,620$ & $0,009^{*}$ & $\begin{array}{c}\mathrm{H}_{0} \\
\text { Red }\end{array}$ \\
\hline & & Sözel karşılaştırma problemleri & $\begin{array}{l}\text { Pozitif } \\
\text { Negatif } \\
\text { Eşit } \\
\text { Toplam }\end{array}$ & $\begin{array}{c}10 \\
1 \\
5 \\
16\end{array}$ & $-2,640$ & $0,008^{*}$ & $\begin{array}{c}\mathrm{H}_{0} \\
\text { Red }\end{array}$ \\
\hline
\end{tabular}

Tablo 7'de görüldüğü üzere erken matematiksel akıl yürütme becerileri ölçme alt boyutuna ait tüm alt boyutlarına ait yönergelerde deney grubu lehine anlamlı fark görülmüştür. Bu sonuca göre deney grubundaki çocuklara haftada iki gün olmak üzere sekiz hafta süreyle araştırmacı tarafından uygulanan PDME'nin çocukların erken matematiksel akıl yürütme becerilerinden ölçme becerilerinin gelişiminde daha etkili olduğu söylenebilir. Çalışma grubunu oluşturan çocukların erken matematiksel ak1l yürütme becerilerinden veri analizi-olasılık becerilerinde gösterdiği gelişme ise sonraki aşamada incelenmiştir. Bunun için öncelikle kontrol grubunun ön-test ve son-test puanları Wilcoxon İşaretli Sıralar Testi ile karşılaştırılmıştır.

Tablo 8. Kontrol Grubu Ön-test Puanları ile Son-test Puanları Arasındaki Farkın Analizi: Eşleştirilmiş Örnekler İçin Non-parametrik Wilcoxon İşaretli Sıralar Testi

\begin{tabular}{|c|c|c|c|c|c|c|c|}
\hline & oyut & Yönergeler & & $\mathbf{N}$ & $\mathbf{Z}$ & $\mathbf{p}$ & Karar \\
\hline & & & Pozitif & 10 & & & \\
\hline & & & Negatif & 1 & & & $\mathrm{H}_{0}$ \\
\hline & $\Xi$ & Şekıllerın ozellıklerını bılme & Eşit & 5 & $-2, / 39$ & $0,006^{*}$ & Red \\
\hline & 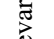 & & Toplam & 16 & & & \\
\hline & $\Xi$ & & Pozitif & 7 & & & \\
\hline & $: 三$ & & Negatif & 0 & & & $\mathrm{H}_{0}$ \\
\hline 咅 & & Grafik oluşturma & Eşit & 9 & $-2,388$ & $0,017 *$ & Red \\
\hline$\frac{2}{\pi}$ & & & Toplam & 16 & & & \\
\hline $0_{0}^{0}$ & & & Pozitif & 8 & & & \\
\hline 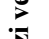 & & Resim inceleme ve resimdeki durumu & Negatif & 2 & -2200 & $0028 *$ & $\mathrm{H}_{0}$ \\
\hline$\stackrel{\mathbb{N}}{\Xi}$ & & tahmin etme & Eşit & 6 & $-2,200$ & $0,028^{*}$ & Red \\
\hline$\grave{\Xi}$ & $\Xi$ & & Toplam & 16 & & & \\
\hline 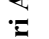 & $\overline{8}$ & & Pozitif & 4 & & & \\
\hline$\sum^{\overline{0}}$ & లี & Grafik okuma ve sonuclarını sövleme & Negatif & 1 & -1511 & 0131 & $\mathrm{H}_{0}$ \\
\hline & $\Xi$ & 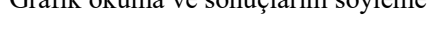 & Eşit & 11 & $-1, J 11$ & 0,151 & Kabul \\
\hline & 污 & & Toplam & 16 & & & \\
\hline & & & Pozitif & 9 & & & \\
\hline & & Olas 1lik helirtme & Negatif & 2 & -2190 & $0029 *$ & $\mathrm{H}_{0}$ \\
\hline & & Uasmк Demrme & Eşit & 5 & $-2,190$ & $0,029^{\prime \prime}$ & Red \\
\hline & & & Toplam & 16 & & & \\
\hline
\end{tabular}


Tablo 8'de görüldüğ̈̈ üzere erken matematiksel akıl yürütme becerileri veri analizi alt boyutuna ait yönergelerden şekillerin özelliklerini bilme $(\mathrm{p}=0,006)$, grafik oluşturma $(\mathrm{p}=0,0017)$ ve resim inceleme ve resimdeki durumu tahmin etme $(p=0,0028)$, olasıllk belirtme $(p=0,0029)$ alanlarında deney grubu lehine anlamlı fark görülmüş ve hipotez O'ın reddine karar verilmiştir. Deney grubunun erken matematiksel akıl yürütme becerileri, veri analizi olasılık alt boyutunda gösterdiği gelişme ise son-test verilerinin ön-test verileri ile karşılaştırılması yoluyla yapılmıştır. Bu amaçla Tablo 9'da deney grubu ön-test ve son-test verilerinin Wilcoxon İşaretli Sıralar Testi sonuçlarına yer verilmiştir. Tablo 9. Deney Grubu Ön-test Puanları ile Son-test Puanları Arasındaki Farkın Analizi: Eşleştirilmiş Örnekler İçin Non-parametrik Wilcoxon İşaretli Suralar Testi

\begin{tabular}{|c|c|c|c|c|c|c|c|}
\hline \multicolumn{2}{|c|}{ Alt Boyut } & \multirow{2}{*}{$\begin{array}{l}\text { Yönergeler } \\
\text { Şekillerin özelliklerini bilme }\end{array}$} & \multirow{2}{*}{\begin{tabular}{l}
\multicolumn{1}{c}{ Sıralar } \\
Pozitif \\
Negatif \\
Eşit \\
Toplam \\
\end{tabular}} & \multirow{2}{*}{$\begin{array}{c}\mathbf{N} \\
14 \\
0 \\
2 \\
16 \\
\end{array}$} & \multirow{2}{*}{$\begin{array}{c}\mathbf{Z} \\
-3,310\end{array}$} & \multirow{2}{*}{$\frac{\mathbf{p}}{0,001 *}$} & \multirow{2}{*}{$\begin{array}{c}\text { Karar } \\
\mathrm{H}_{0} \\
\text { Red }\end{array}$} \\
\hline \multirow{4}{*}{ 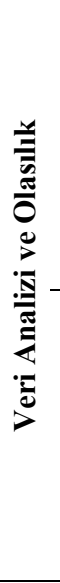 } & \multirow{2}{*}{ 声 } & & & & & & \\
\hline & & Grafik oluşturma & $\begin{array}{l}\text { Pozitif } \\
\text { Negatif } \\
\text { Eşit } \\
\text { Toplam } \\
\end{array}$ & $\begin{array}{c}14 \\
0 \\
2 \\
16\end{array}$ & $-3,308$ & $0,001 *$ & $\begin{array}{c}\mathrm{H}_{0} \\
\text { Red }\end{array}$ \\
\hline & \multirow{2}{*}{ 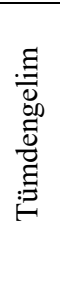 } & $\begin{array}{l}\text { Resim inceleme ve resimdeki durumu tahmin } \\
\text { etme }\end{array}$ & $\begin{array}{l}\text { Pozitif } \\
\text { Negatif } \\
\text { Eşit } \\
\text { Toplam }\end{array}$ & $\begin{array}{c}12 \\
1 \\
3 \\
16\end{array}$ & $-3,118$ & $0,002 *$ & $\begin{array}{c}\mathrm{H}_{0} \\
\text { Red }\end{array}$ \\
\hline & & Grafik okuma ve sonuçlarını söyleme & $\begin{array}{l}\text { Pozitif } \\
\text { Negatif } \\
\text { Eşit } \\
\text { Toplam }\end{array}$ & $\begin{array}{c}11 \\
1 \\
4 \\
16\end{array}$ & $-2,825$ & $0,005^{*}$ & $\begin{array}{c}\mathrm{H}_{0} \\
\text { Red }\end{array}$ \\
\hline
\end{tabular}

Tablo 9'da görüldüğü üzere erken matematiksel akıl yürütme becerileri veri analizi-olasılık alt boyutuna ait yönergelerin tamamında deney grubu lehine anlamlı fark görülmüştür. Bu sonuca göre deney grubundaki çocuklara haftada iki gün, 20 dakika olmak üzere sekiz hafta süreyle araştırmacı tarafindan uygulanan PDME'nin çocukların erken matematiksel akıl yürütme becerilerinden veri analizi-olasılık becerilerinin gelişiminde daha etkili olduğu söylenebilir.

Deney grubundaki çocuklar müzik etkinliklerini kontrol grubundan farklı olarak bir müzik eğitimcisi ile yürütülmüştür. Ayrıca etkinliklerde piyano çalgısının öğretmen ve çocuklar tarafından kullanımı sağlanmıştır. Tüm bunlar dikkate alındığında, erken çocukluk döneminde müzik etkinliklerinin sınıf öğretmeni yerine müzik eğitimcisi tarafından piyano desteğiyle verilmesinin çocukların akademik yaşamlarında önemli rol oynayacak bir beceri olan matematiksel akıl yürütme becerilerinin gelişiminde iyi bir temel oluşturmaya katkı sağladığı söylenebilir.

Yapılan bu araştırmanın sonucunda ayrıca ortaya çıkmıştır ki çocuklar sınıf öğretmenince işlenen müzik etkinliklerinin bilişsel faydalarını, müzik öğretmeninin etkinliklerine göre daha az görmüştür. Türkiye'deki milli eğitim sisteminde anasınıfları ve ilkokullarda dal eğitimlerinin dal öğretmenleri yerine sınıf öğretmeni tarafından verilmesi durumu müzik derslerinin de sınıf öğretmeni tarafından işlenmesi sonucunu getirmiştir (MEB, 2013). Sınıf öğretmenleri lisans eğitimlerinde çalg1 eğitimi olarak ayrıntılı bir öğrenim görmemektedir. Haftada iki saat olmak üzere müzik eğitim yaklaşımları ve temel müziksel becerileri içeren dersleri iki dönem süresince almaktadırlar (Anadolu Üniversitesi, 2019; Gazi Üniversitesi, 2019b; Marmara Üniversitesi, 2019b). Araştırmada kullanılmış olunan PDME için uzman görüşleri alınırken görüşülen öğretim üyeleri de bu konuya da değinmişler, öğretmenler kendilerini yeterli görse bile hazırlanan müzik etkinliklerinin içeriklerinin oldukça yetersiz olduğundan yakınmışlardır. Bu sorunun çözümü için meslek hayatı süresince bir hizmet içi eğitim olanağının da maliyet ve zaman açısından uygun olmaması da araştırma sonucu ortaya çıkan bu sonuçta bir etken olabileceği düşünülebilir.

Kontrol grubuna ait bulguları yorumlarken bu gruptaki çocukların da eğitim süreci içerisinde müzik etkinliklerine yer verildiği göz önüne alınmalıdır. Bu etkinlikler müzik öğretmeni tarafından değil, sınıf öğretmeni tarafından yürütülmüştür. Kontrol grubunun müzik öğretimi araç-gereçleri ile ilgili olanakları, daha önce de değinilmiş olduğu gibi deney grubu sınıfının olanakları ile benzerdir. 
Müzik öğretimi araç-gereçleri açısından iki grup arasındaki en önemli farklar kontrol grubunun müzik etkinliklerini sınıf öğretmeni ile işlemesi ve etkinliklerde piyano kullanılmamış olunmasıdır.

Kontrol grubu çocuklarının standart olmayan birimlerle uzunluk-ağırlık, alan-hacim ölçme ve sonuçları karşılaştırma, eldeki sonuçların doğruluğunu anlama, şekillerin özelliklerini bilme, grafik oluşturma, resim inceleme-resimdeki durumu tahmin etme ve olasılık belirtme alanlarında gösterdiği gelişmenin bir sebebi de okul öncesi eğitim programının eklektik yapısı olabilir. Programda eğitimöğretim süreci planlanıp, uygulanırken çocukların hazır bulunuşluk düzeylerine, gelişimsel özelliklerine, ilgi-dikkat durumlarına önem verilmesine dikkat çekilmiştir. Ayrıca öğrenme merkezlerinde yer alan çeşitli öğrenme araç gereçlerinden de çocukların eğitimsel ihtiyaçları doğrultusunda yararlanılması istenmiştir. Tüm bu etmenler de sınıf öğretmeninin kalitesi ile birleştiğinde çocukların diğer gelişimsel becerilerinde olduğu gibi, erken matematiksel akıl yürütme becerilerinde de gelişmeye olanak sağlamış olabilir.

Kontrol grubunu oluşturan sınıfin bulunduğu ilkokulda da deney grubunda olduğu gibi müzik etkinlikleri için müzik eğitimi araç-gereçleriyle donatılmış bir müzik odası bulunmamaktadır. Derste sadece Marakas gibi ritim çalgıları kullanılmaktadır. Tüm bu etmenler sonucunda müzik etkinliklerinde öğretmenin ya da öğrencilerin bağlama, gitar ya da piyano gibi bir çalgı kullanımı söz konusu olmamıştır. $\mathrm{Bu}$ durum da kontrol grubunda müzik etkinliklerinin niteliğini düşürürken araştırma sonucunda kontrol grubu çocuklarının erken matematiksel akıl yürütme becerilerinde daha az gelişim göstermelerine sebep olmuş olabilir. PDME için uzman görüşleri alınırken akademisyenler de sınıflardaki müzik öğretimi araç-gereçlerinin yetersiz olabileceğini belirtmişlerdir.

\section{Sonuç, Tartışma ve Öneriler}

Araştırmanın sonucunda, kontrol grundaki çocukların ön-test ve son-test verileri karşılaştı̆̆ında çocukların erken matematiksel akıl yürütme becerilerinden standart olmayan birimlerle ölçme ve sonuçları karşılaştırma (uzunluk ve ağırlık, alan ve hacim), eldeki sonuçların doğruluğunu anlama; şekillerin özellikleri bilme, grafik oluşturma, resim inceleme ve resimdeki durumu tahmin etme, olasılık belirtme alanlarında gelişme kaydedildiği görülmüştür. Deney grubundaki çocuklar ise erken matematiksel akıl yürütme becerilerinin tüm alt boyutlarına ait maddelerde gelişme kaydetmiştir. Buna dayanarak anasınıflarında haftada iki gün, 20 dakika olmak üzere sekiz hafta süreyle okul öncesi öğretmeni yerine bir müzik eğitimcisi tarafından uygulanan PDME'nin çocukların erken matematiksel akıl yürütme becerilerinin gelişiminde daha etkili olduğu sonucuna varılmıştır.

1995 'te Schlaug, Jäncke, Huang, Staiger ve Steinmetz tarafından yapılan araştırmada en az 7 yaşından önce her hangi bir çalgıya başlayan çocukların beyinlerinin iki yarım küresi arasında, sinirsel iletişimi ve çok hızlı bilgi akışını sağlayan köprüde (corpus callosum) kalınlaşma meydana geldiği saptanmıştır. Çalgı eğitimi aracılığıyla, iki beyin yarım küresi arasındaki bağlantıyı sağlayan sinir liflerinin sayısının artmakta olduğu düşünülmüştür. Araştırmada kontrol ve deney grupları 6 yaşındaki çocuklardan oluşturulmuştur. Deney grubu haftada en az 2,5 saat iki elle çalınan bir çalgi eğitimi almaya başlamış, kontrol grubu ise hiç müzik eğitimi almayan çocuklardan oluşturulmuştur. Ǘç yıl sonra her iki grubun da beyinlerinin Manyetik Rezonans filmleri çekilerek yapılan değerlendirmede çalg1 çalan çocukların beyinlerinde iki küre arasındaki bağlantıyı sağlayan köprüdeki (corpus callosum) sinir liflerinde \%25 artış görülmüştür. Hiç çalgı çalmayan, çalgıya başlayıp erken bırakan, ya da çalgıya yetersiz zaman ayıran çocukların beyninde hiçbir değişme saptanmamıştır. Bu araştırmada da elde edilen sonuçlar çalgı eğitiminin bilişsel becerilere etkisi açısından benzerlik göstermektedir.

Bilhartz, Bruhn, \& Olson (2000) tarafindan yapılan bir çalışmada okul öncesinde yapılandırılmış bir müzik öğretim programının bilişsel gelişime etkisi incelenmiştir. 4-6 yaş grubunda 71 çocuk araştırmanın çalışma grubunu oluşturmuştur. Veri toplama aracı olarak Stanford-Binet Zekâ Ölçeği’nin 6 alt ölçeği ile Küçük Çocuklar Müzik Becerileri Değerlendirme Ölçeği kullanılmıştır. Bu ölçeklerle yapılan ön-testin ardından deney grubuna 30 hafta boyunca haftada 75 dakika, aile katılımı ile müzik öğretim programı uygulanmıştır. Araştırma sonucunda bu araştırmada da olduğu gibi deney grubu lehine anlamlı fark bulunmuştur. Ancak bu fark; çalışma grubu cinsiyet, etnik köken, aile eğitim durumu, ekonomik duruma göre düzenlendiğinde mevcuttur. 
Piyano eğitiminin, başka bir bilişsel beceri olan erken çocuklukta uzay-zamansal çıkarsama becerisini arttırdığı hipotezi test edilen bir araştırmada okul öncesi eğitim almakta olan 78 çocuk araştırmanın çalışma grubunu oluşturmuştur. Bu çocuklardan 34'ü bireysel piyano dersi, 20'si özel bilgisayar dersi almış; 24 çocuk ise diğer kontrol grubunu oluşturmuştur. Veri toplama aracı olarak Wechsler Okul Öncesi ve İlköğretim Zekâ Testinin Performans Alt Testi kullanılmıştır. Verilere uygulanan Tek Yönlü Varyans Analizi sonucunda bireysel piyano dersi alan grup lehine anlamlı fark bulunmuştur. (Rauscher vd., 1997).

Dikici tarafından 2002 yılında yapılan araştırma, Orff öğretisi temelinde verilen müzik eğitiminin 5-6 yaş çocuklarının matematik becerilerine etkisinin incelenmesi amacıyla yapılmıştır. Araştırma deney grubunda 24, kontrol grubunda 24 olmak üzere toplam 48 çocuk üzerinde yürütülmüştür. Araştırmada çocuk ve ailesi hakkında bazı bilgileri içeren Kişisel Bilgi Formu, çocukların matematik becerilerini belirlemek için ön-test ve son-test olarak kullanılan Test of Early Mathematics Ability-2 ve Orff Öğretisi temelinde hazırlanarak pilot çalışması yapılmış olan 24 eğitim programı kullanılmıştır. Verilerin istatistiksel analizi sonucunda deney grubundaki çocukların ön-test ve son-test matematik yeteneği puanları arasındaki farkın bu araştırmada olduğu gibi anlamlı olduğu bulunmuştur.

Kuşçu'nun 2010 tarihli araştırmasında Orff-Schulwerk yaklaşımı kullanılarak yapılan müzik etkinliklerinin bir erken bilişsel beceri olan dikkat becerilerine etkisini incelemek amaçlanmıştır. Araştırmanın çalışma grubunu, yansız atama ile seçilen 5-6 yaş grubu çocuklarından 10 deney grubunda ve 10 kontrol grubunda olmak üzere toplam 20 çocuk oluşturmaktadır. Çocukların dikkat toplama becerilerini belirlemek amacıyla Frankfurter Beş Yaş Çocukları için Dikkat Toplama Testi kullanılmıştır. Test, çocuklara ön-test ve sontest olarak uygulanmış, deneme grubuna 20 hafta sonra tekrarlanmıştır. Elde edilen veriler ve analiz sonuçları Orff yaklaşımı ile hazırlanan müzik etkinliklerinin 5-6 yaş grubu çocukların dikkat becerilerini geliştirdiğini göstermektedir.

Okul öncesi eğitim programını müziksel becerilerin gelişimi açısından değerlendirilmesinin amaçlandığı bir araştırmanın sonucunda ise müzikal becerilerin kazanımlarla ilişkilendirilmesine yönelik programdaki rehberliğin yeterli olmadığ 1 tespit edilmiştir. Ayrıca, programın çocukların, müzikal ilgi, bilgi, beceri ve tutumlarının değerlendirilmesi yönünden güçlendirilmesi gerektiği sonucuna varılmıştır. Sonuçlar doğrultusunda Okul Öncesi Eğitim Programı’nın kazanımlar, öğrenme süreci ve değerlendirme basamakları yönünden gözden geçirilmesi, çocukların müzikal becerilerinin gelişimi ve desteklenmesi konusunda güçlendirilmesi gerektiği tespit edilmiştir (Kandır \& Türkoğlu, 2015). Kandır ve Türkoğlu'nun araştırmasında elde edilen veriler ışığında bu araştırmada müziksel içeriği zengin etkinlikler bir müzik öğretmeni tarafindan hazırlanmış, uygulanmış ve etkinliklerin çocukların bilişsel bir beceri olan matematiksel akıl yürütme becerilerine katkı sağladığı görülmüştür.

Yukarıda değinilen diğer araştırma sonuçlarında da görüldüğ̈̈ üzere, bu araştırmada elde edilen bulgular, yapılan benzer araştırma sonuçlarıyla karşılaştırıldığında paralellik göstermektedir. Bu sonuçlar ışı̆̆ında aşağıdaki öneriler sunulabilir:

1. Anasınıflarında müzik öğretimi araç-gereci olarak bir piyano bulundurulması önerilebilir. Piyanonun maliyetinin karşılanamaması durumunda ise elektronik piyano ya da elektronik org gibi daha uygun maliyetli alternatifler temin edilebilir. Okul öncesi öğretmenlerine piyano eğitimi verilmesi ile ana sınıflarında müzik etkinliklerinde piyano kullanımı sağlanabilir.

2. Üniversitelerin okul öncesi öğretmenliği bölümlerinde müzik etkinlikleri ile ilgili derslerin kredisi arttırılarak öğretmen adaylarının okul çalgılarının kullanımı, drama, dans, şarkı söyleme, müzikli oyunlar, ritim çalışmaları gibi etkinliklerinin planlama ve uygulamasına yönelik yeterli içerikte bir eğitim almaları önerilir. Yine de okul öncesi öğretmen adaylarının müzik etkinlikleri ile ilgili olarak müzik öğretmen adayları kadar kapsamlı bir eğitim alamayacakları açıktır.

3. $\mathrm{Bu}$ araştırma erken piyano eğitiminin bilişsel becerilere etkisini kanıtlar ve bu alandaki diğer çalışmaları destekler niteliktedir. $\mathrm{Bu}$ durumda müzik öğretmenliği lisans programlarında piyanoyu ana çalg1 kategorisine sokmak, ders kredisini arttırmak ve içeriğini yoğunlaştırmak yerinde bir karar olacaktır. Bu şekilde müzik öğretmenlerinin piyano çalmaktaki yeterlilikleri de artmış olacaktır. 
4. Piyano öğretimi, piyano çalma becerilerinin yanı sıra piyano çalgısının farklı yaş gruplarına nasıl öğretilmesi gerektiğini içeren değerli bir disiplindir. Özellikle okul öncesi çağdaki çocukların piyanoyu nasıl kullanması gerektiğini öğretmek için piyano öğretimi hakkında öğretmenin eğitim almış olması özellikle gereklidir. Bu sebeple müzik öğretmenliği lisans programlarına piyano öğretimi ile ilgili derslerin ilgili eğitim programlarına eklenmesi önerilir.

5. Müzik öğretmenliği lisans programlarının içeriğinde eğitim bilimleri ile ilgili dersler öğretmen adaylarının erken müzik eğitimi ile ilgili bir fikir sahibi olmasını sağlayabilmektedir. Yine de, Müzik öğretmenliği lisans programlarında seçmeli olarak bulunan ya da programlarında yer almayan okul öncesi eğitimde müzik etkinlikleri ile ilgili derslerin programda zorunlu ders olarak bulunması önerilir.

6. Okul öncesi ve müzik öğretmenliği lisans programlarındaki erken müzik eğitimi ile ilgili geliştirilmelerin yapılmasının ardından anasınıflarında yer verilen müzik etkinliklerinin okul öncesi öğretmeninin rehberliğinde müzik öğretmeni tarafindan işlenmesi önerilmektedir. Bu şekilde hem etkinlikler çocukların ilgi, gelişim düzeyi ve yeterliliklerine göre planlanacaktır,

7. Anasınıfları ve kreşlere müzik öğretmeni ataması yapılması durumunda müzik öğretmenlerinin mesleki eğitim süreçlerinde çalgı eğitimi almış olmaları sebebiyle müzik etkinliklerinde çalgı kullanımı da mümkün olabilmektedir.

8. Her anasınıfında okul çalgıları, piyano, gitar, bağlama, gibi çalgılar bulundurmak maliyet açısından zorlayıcı olabilir ancak okullarda bir müzik odası oluşturarak bu odadaki müzik eğitimi araç gereçlerinin öğrenciler tarafından ortak kullanımı maliyeti düşürebilir. 


\section{Kaynakça}

Agay, D. (1992). Learning to play piano-Book 1. Yukon: Yorktown.

Aladağ, A. (2009). Illköğretim ögrencilerinin orantısal akıl yürütmeye dayalı sözel problemler ile gerçekçi cevap gerektiren problemleri çözme becerilerinin incelenmesi (Yayımlanmamış Yüksek lisans tezi). Adana: Çukurova Üniversitesi.

Altıparmak, K. \& Öziş, T. (2005). Matematiksel ispat ve matematiksel muhakemenin gelişimi üzerine bir inceleme. Ege Ë̆itim Dergisi, 6(1), 25-37.

Anadolu Üniversitesi. (2019). Okul öncesi ögretmenliği lisans programı ders içerikleri.http://oo. education.ankara.edu.tr/ okul-oncesi-ogretmenligi- lisans-programi/ adresinden erişilmiştir.

Aral, N., Kandır, A., \& Yaşar, M. (2002). Okul öncesi eğitim ve okul öncesi eğitim programı. İstanbul: Ya-Pa.

Artan, İ. (2001). Okulöncesi dönemde işitsel algı ve müzik. A. Öztürk (Yay. Haz.) Müzik öğretimi. Eskişehir: Anadolu Üniversitesi, Açıköğretim Fakültesi.

Bal-İncebacak, B., \& Ersoy, E. (2016). 7. sınıf öğrencilerinin matematiksel muhakemelerinin TIMMS'e göre analizi. Uluslararası Sosyal Araştırmalar Dergisi, 9(46), 474-481.

Bastien, J. (1987). Piano for the young beginner. California: Kjos Music Company.

Billhartz, T., Bruhn, R., \& Olson, J. (2000). The effect of early music training on childs cognitive development. Journal of Applied Developmental Psychology, 20(4), 615-636.

Çevikkaya, İ. (2014). Minik müzik gezginleri-çocuklar için öykülü piyano metodu. Ankara: Müzik Eğitimi.

Dehart, G., Sroufe, L., \& Cooper, R. (2004). Child development: Its nature and course. New York: Mcgraw-Hill Education.

Dikici, A. (2002). Orff tekniği ile verilen müzik eğitiminin matematik yeteneğine etkisinin incelenmesi (Yayımlanmamış Doktora Tezi). Ankara: Ankara Üniversitesi.

Doğan, C. (2018). Anasınıfina devam eden çocukların matematiksel akll yürütme becerilerine piyano destekli müzik etkinliklerinin etkisi (Yayımlanmamış Doktora Tezi). Ankara: Gazi Üniversitesi.

Doğan, C. ve Tecimer, B. (2017). The evaluation of preschool and primary educational music activities in Turkey based on teachers' opinions (Ankara sample). Journal of Academic Social Science Studies, 64(3), 497-506.

Doğan, C. \& Tecimer, B. (2018). The effect of piano-assisted music activities on early mathematical reasoning skills of preschoolers. 33. World Conference of International Society for Music Education. Baku, Aizerbaijan.

Dokuz Eylül Üniversitesi. (2019a). Müzik öğretmenliği lisans programı ders içerikleri. http://www.deu.edu.tr/derskatalog/2015-2016/tr/bolum1095tr.html (12.11.2019).

English, L. D. (2004). Mathematical and analogical reasoning of young learners. USA: Lawrence Erlbaum Associates.

Fathima, S. \& Rao, D. B. (2008). Reasoning ability of adolescent students. New Delhi: Discovery.

Faber, N. \& Faber, R. (2007). My first piano adventure. lesson book a:pre-reading. Wisconsin: Hal Leonard.

Gander, M. J. \& Gardiner, H. W. (2010). Çocuk ve ergen gelişimi. Onur, B. (Ed). Ankara: İmge.

Gazi Üniversitesi. (2019a). Müzik öğretmenliği lisans programı ders içerikleri. http://gefguzelsanatlar-muzik.gazi.edu.tr/posts/view/title/ogretim-programi- 58 adresinden erişilmiştir.

Gazi Üniversitesi. (2019b). Okul öncesi ögretmenliği lisans programı ders içerikleri. http://gbp.gazi.edu.tr//htmlProgramHakkinda.php adresinden erişilmiştir.

Goswami, U. (2004). Inductive and deductive reasoning. U.Goswami (Editör). Handbook of Childhood Cognitive Development. New Jersey: Blackwell.

Gromko, J. E. \& Poorman, A. S. (1998). The effect of music training on preschooler's spatial temporal task performance. Journal of Research in Music Education, 46(1), 173-181.

Gültek, B. (Ed.). (2010). Avrupa piyano metodu. Ankara: Epilog.

Isenberg, J. P. \& Jalongo, M. R. (2000). Creative expression and play in early childhood. New Yok: Merrill. 
Kandır, A. \& Türkoğlu, D. (2015). MEB 2013 okul öncesi eğitim programı'nın müzikal becerilerin gelişimi yönünden değerlendirilmesi. Hacettepe University Faculty of Health Sciences Journal, 1(2), 339-350.

Kaya, S. \& Ayan, B. (2016). Okul öncesinde müzik ve hareketin öğrenme üzerindeki etkisi. Erzincan University Faculty of Education Journal, 18(1), 463-480. DOI: 10.17556/jef.04848.

Köknel, Ö. (2003). Akıl ile düşünce gücü. İstanbul: Altın Kitaplar.

Kasap, B. (2005). Suzuki piyano okulu metodu. İnönü Üniversitesi Eğitim Fakültesi Dergisi, 6(10), 71-86.

Kuşçu, Ö. (2010). Orff-schulwerk yaklaşımı ile yapılan müzik etkinliklerinin okulöncesi dönemdeki çocuklarının dikkat becerilerine etkisi (Yayımlanmamış Yüksek Lisans Tezi). Konya: Selçuk Üniversitesi.

Marmara Üniversitesi. (2019a). Müzik öğretmenliği lisans programı ders içerikleri. Web: http://mzo.aef.marmara.edu.tr/lisans-programi (11.11.2019).

Marmara Üniversitesi. (2019b). Okul öncesi öğretmenliği lisans programı ders içerikleri. http://okl.aef.marmara.edu.tr/lisans-programi/ sayfasından erişilmiştir.

Milli Eğitim Bakanlığı. (2013). Temel eğitim genel müdürlüğü okul öncesi eğitim programı. Ankara: MEB.

Nikoltsos, C. (2000). The art of teaching art in early childhood education. ERIC Digest. No: ED443575.

Olgun, S. \& Toluk Uçar, Z. (2007). İlköğretimde etkinlik temelli matematik $\quad$ ögretimi. Ankara: Anı Yayınc1l1k, Türkiye.

Piaget, J. (2011). Çocukta akll yürütme ve karar verme. ( Siyavuşgil, S. Çev.). İstanbul: Palme.

Rauscher, F., Shaw, G., Levine, L., Wright, E., Dennis, W., \& Newcomb, R. (1997). Music training causes long-term enhancement of preschool children's spatial-temporal reasoning. Neurological Research, 19(1), 2-8.

Rauscher, H., Gordon L., Shaw G., \& Katherine N. (1993). Music and spatial task performance. Journal of Nature, 400, 365-611.

Schlaug, G., Jäncke, L., Huang, Y., Staiger, J. F., \& Steinmetz, H. (1995). Increased corpus callosum size in musicians. Neuropsychologia, 33(8), 1047-1055.

Suzuki, S. (1978). Suzuki Piano school volume 1. New Jersey: Birch Tree Group.

Thomass-Lee, P. (2003). Piano pedagogy for four to five year olds: an analysis of sellected piano methods for teaching preschool children (Yayımlanmamış Doktora Tezi). Georgia: Georgia Üniversitesi.

Thompson, J. (2010). Kolay piyano kursu. İstanbul: Porte.

Umay, A. (2003). Okul öncesi öğretmen adaylarının matematik öğretmeye ne kadar hazır olduklarına ilişkin bazı ipuçları. Hacettepe Üniversitesi Ĕ̈itim Fakültesi Dergisi, 5, 194-203.

Umay, A. \& Kaf, Y. (2005). A study on flaved reasoning in mathematics. Hacettepe University Journal of Education, 28, 188-195.

Ulusoy, A., Aytar, A., Akyol, A., Subaşı, G., Ünver, G., \& Koç, G. (2014). Eğitim psikolojisi. Ankara: Anı Yayınc1lik.

Uzsler, M., Gordon, S., \& Smith, S. (2000). The well-tempered keyboard teacher. Newyork: Schimer.

Ürfioğlu, A. (2000). Bebeklik ve okul öncesi dönemde müziğin gelişimi ve eğitimi. İstanbul: Ya-Pa.

Yalım, N. (2009). 5-6 yaş çocuklarında matematiksel şekil algısı ve sayı kavramının gelişiminde drama yönteminin etkisi (Yayımlanmamış Doktora Tezi). Konya: Selçuk Üniversitesi. 